\title{
humanidades
}

Revista humanidades

Diciembre, 2014 • Volumen 4 • ISSN 2215-3934 • pp. 1-103

\section{Lesiones al gobierno y organización universitarios}

\section{Injuries to government and university organization}

DOI: http://dx.doi.org/10.15517/h.v4i1.16327

07-Abril-2014 / Aceptado: 27-Junio-2014

\section{Luis Baudrit Carrillo}

Doctor, profesor Catedrático de la Facultad de Derecho y Director de la Oficina Jurídica de la Universidad de Costa Rica.

Correo electrónico: luis.baudrit@ucr.ac.cr

Más sobre el autor:

Todos los derechos reservados. Universidad de Costa Rica. Esta revista se encuentra licenciada con Creative Commons Reconocimiento-NoComercial-SinObraDerivada 3.0 Costa Rica.

Correo electrónico: humanidades.eeg@ucr.ac.cr / Sitio web: http://revistas.ucr.ac.cr/index.php/humanidades 
Las Universidades públicas poseen plena capacidad jurídica para, entre otras funciones, autogobernarse y auto organizarse ${ }^{1}$. Su régimen de autonomía especial supera en mucho al que corresponde a las instituciones autónomas, que se encuentra reducido a independencia administrativa ${ }^{2}$, con excepción de la Caja Costarricense de Seguro Social que, además de la autonomía administrativa, posee la de gobierno de los seguros sociales ${ }^{3}$, aunque carece de atribuciones para darse su propia organización, tema en el que se encuentra supeditada a la ley. Las corporaciones municipales, por su parte, también poseen autonomía administrativa y de gobierno, pero no de organización ${ }^{4}$.

La plena capacidad jurídica que ostentan las Universidades garantiza constitucionalmente el ejercicio de la libertad necesaria para desarrollar en forma directa sus propias actividades, sin necesidad de obtener autorizaciones o aprobaciones de órganos o entes ajenos. Esta capacidad jurídica plena se complementa con una amplia esfera de protección conocida como independencia o autonomía, que impide que órganos o entes, públicos o privados, extraños a las Universidades, puedan interferir en cualquiera de las múltiples actividades universitarias, ya fuese impidiéndolas u obstaculizándolas, o ya fuese imponiendo decisiones, desplazando o sustituyendo a las autoridades legítimas o a los órganos universitarios en el ejercicio de sus funciones y en la atribución de sus competencias. 
Hace pocos años ocurrieron lamentables acontecimientos en algunas Universidades costarricenses, que sufrieron las consecuencias de la arbitrariedad y del despotismo de funcionarios del Poder Judicial y de autoridades de la Fuerza Pública y, por otra parte, de funcionarios de la Contraloría General de la República.

Algunos meses, antes de que una funcionaria de la Contraloría General de la República — como si fuera su superiora jerárquica - comunicara órdenes terminantes al Instituto Tecnológico de Costa Rica (que luego

Invasiones policiales a los campus serán comentadas), el campus de la Universidad de Costa Rica fue invadido por varias docenas de miembros del Organismo de Investigación Judicial y de la Fuerza Pública, con una Fiscal del Ministerio Público a la cabeza, con el pretexto de detener a una persona que, supuestamente, había cometido un delito - nunca comprobado-. Esto ocurrió a mediados del mes de abril de $2010^{5}$.

En mayo de ese mismo año, mediante otro aparatoso operativo, funcionarios del Ministerio Público y agentes del Organismo de Investigación Judicial allanaron oficinas del Instituto Tecnológico de Costa Rica, atendiendo una denuncia interpuesta por la Auditoría interna del propio Instituto sobre supuestos manejos irregulares en el presupuesto ${ }^{6}$. 
A ambos acontecimientos, de modo especial al primero, se les dio una enorme cobertura y divulgación por los principales medios de comunicación colectiva. Los periódicos, televisoras y radioemisoras de mayor alcance en el país expusieron lo ocurrido de forma tergiversada, atribuyéndole a las instituciones estatales de educación superior haberse arrogado una inexistente extraterritorialidad y una excesiva autonomía.

Dichosamente, con el paso del tiempo estas noticias fueron perdiendo notoriedad y, poco a poco, los relatos peyorativos para las Universidades terminaron por reducirse y por olvidarse. La mala imagen de las Universidades, injustamente proyectada, se fue diluyendo y podría afirmarse que los daños causados quedaron relegados en el pasado.

A partir de entonces, como siempre se había hecho antes, cualquier operativo policial que fuera necesario practicar dentro de los campus, ha sido coordinado con las autoridades universitarias, quienes han brindado la más amplia colaboración a los agentes del Organismo de Investigación Judicial o de la Fuerza Pública.

La inusitada invasión de fuertes contingentes policiales fue una medida innecesaria, excesiva y absolutamente injustificada. El asunto no pasó a más. La invasión a las Universidades y la interferencia que de hecho se dio en 
algunas de sus actividades cesó en pocas horas y no tuvo mayores consecuencias. En la capacidad jurídica universitaria y en su autonomía no persistió lesión o restricción alguna.

Después de haber ocurrido los acontecimientos relatados, en noviembre de ese mismo año, el Instituto Tecnológico de Costa Rica —institución de educación superior universitaria estatal — sufrió una grave lesión a su capacidad jurídica y autonomía, que pasó inadvertida a los medios de comunicación y a la ciudadanía, pero que ha tenido consecuencias graves que no tienden a diluirse en el tiempo sino a permanecer e incluso a

\section{Desafortunadas órdenes giradas al Instituto Tecnológico de Costa Rica} acrecentar la magnitud e intensidad de sus perjudiciales efectos. Se trata de un ilegítimo precedente, que podría repetirse, con lesivas consecuencias, aún más severas.

No es esta la primera vez en que algunos funcionarios públicos violan en forma grave, consciente y deliberada, disposiciones establecidas expresamente en el texto de la Constitución Política. Se rehúsan tanto a reconocer la especial naturaleza de las instituciones universitarias, así como a respetar su alto rango jurídico, de índole constitucional.

El asunto en cuestión consistió en que una funcionaria, Gerente de Área de Servicios Sociales, de la División de Fiscalización Operativa y Evaluativa, de la Contraloría General de la República, envió una nota a la Directora Ejecutiva 
de la Secretaría del Consejo Institucional del Instituto Tecnológico de Costa Rica, acompañando un informe preparado por la indicada División sobre mecanismos de control en actividades de vinculación externa realizadas con la colaboración de Fundación Tecnológica de Costa Rica (Fundatec). ${ }^{7}$

La comunicación no emanó del Despacho de la Contralora General. La funcionaria que envió la nota trabaja como Gerente del Área de Servicios Sociales, que está subordinada a la División de Fiscalización y esta, a su vez, depende del Despacho de la Contralora General. A la Directora del Departamento Financiero Contable del Instituto Tecnológico también le fue enviada una nota similar. ${ }^{8}$ Los términos contenidos en esas notas provocan, a la vez, asombro y repugnancia.

Asombro, porque es inaudito que una funcionaria de la Contraloría, de tercera o menor categoría, se arrogue atribuciones de impartir o girar órdenes, de supuesto obligatorio cumplimiento, a algún funcionario u órgano del Instituto Tecnológico, con respecto a los que carece absolutamente de relación como superiora jerárquica.

Repugnancia, porque por una elemental cuestión de respeto a las instituciones y a sus legítimos personeros, una subordinada de la Contraloría no puede dirigirse en esos términos a altos funcionarios del Instituto Tecnológico. Es 
más, ni siquiera la Contralora General podría haberlo hecho correctamente. Admitirlo sería consentir en un desorden y en una desorganización: en una anarquía. Significa indebida interferencia de funcionarios de la Contraloría en la organización y gobierno del Instituto Tecnológico.

Las líneas jerárquicas internas existentes, tanto en la Contraloría General como en el Instituto Tecnológico, deben ser respetadas. Tampoco resultaría legítimo que la Contralora General le ordenara algo al Rector del Instituto Tecnológico. Ella no es su superiora jerárquica, ni él está subordinado institucional, ni jurídicamente a ella.

Además de la improcedencia del envío de la nota comentada, resulta absolutamente inaceptable su carácter prepotente, terminante e imperativo. A continuación se transcriben algunos párrafos de esta, que lo reflejan con claridad:

La información que se solicita en este informe para acreditar el cumplimiento de las disposiciones, deberá remitirse, en los plazos y términos fijados, a la Gerencia del Área de Seguimiento de Disposiciones del órgano contralor. Además, también se requiere que esa Administración le comunique, en un plazo no mayor de cinco días hábiles, el nombre, número de teléfono y correo electrónico de la persona que fungirá como el contacto oficial con esa Área de 
Seguimiento con autoridad para informar sobre el avance y cumplimiento de las disposiciones correspondientes.

Se recuerda que las disposiciones señaladas en el aparte 4.3 del informe de cita, son de acatamiento obligatorio y deberán ser cumplidas dentro de los plazos y términos conferidos para ello. En caso de que se incumpla con esa disposición en forma injustificada dentro del tiempo dado para ello, se le reiterará por una única vez y se fijará plazo para su cumplimiento, pero de mantenerse la desobediencia, una vez. agotado ese plazo, dicha conducta se reputará como falta grave y podrá dar lugar a la imposición de las sanciones previstas en el artículo 69 de la Ley Orgánica de la Contraloría General de la República No. 7428, con garantía del debido proceso. Lo anterior, sin perjuicio de incurrir en otras causales de responsabilidad.

De conformidad con lo establecido por los artículos 343, 346 y 347 de la Ley General de la Administración Pública, contra el presente informe caben los recursos ordinarios de revocatoria y apelación, que deberán ser interpuestos dentro del tercer día posteriores al recibo de esta comunicación, correspondiéndole a esta Área de Fiscalización la resolución de la revocatoria y al Despacho Contralor, la apelación. 
La Contraloría General de la República había realizado un estudio en el Instituto Tecnológico de Costa Rica, con el fin de evaluar los mecanismos de control establecidos en su actividad de vinculación externa remunerada, que desarrolla mediante la Fundación Tecnológica de Costa Rica.

La mencionada funcionaria de la Contraloría General, atribuyéndose facultades de superior jerárquico sobre el Instituto Tecnológico — facultades de las que carece absolutamente - giró órdenes concretas dirigidas tanto al Presidente de la Asamblea Institucional Representativa, como a la propia Asamblea Institucional Representativa. ${ }^{9}$

Se advirtió expresamente en la nota que las órdenes giradas son de acatamiento obligatorio, que su incumplimiento será reputado falta grave, que podrá dar origen a la aplicación de sanciones y que contra el informe caben los recursos ordinarios de revocatoria y apelación.

Existe deber de obediencia o de acatamiento obligatorio en aquellos casos en los que quien gira la orden lo hace en ejercicio de sus funciones legítimas y la persona a quien se gira la orden se encuentra jurídicamente subordinada a la 
primera. ${ }^{10}$ En el caso de desobediencia a las órdenes de la Contraloría, estas serán reiteradas por una sola vez, fijándose plazo para su cumplimiento, y de persistir la desobediencia, se reputará falta grave, originando la suspensión o destitución del infractor. ${ }^{11}$

Sin embargo, la Contraloría General carece de facultades legales para suspender o destituir a quien hubiese desobedecido sus órdenes. Una vez terminado el proceso administrativo en la Contraloría General, esta deberá enviar el expediente al jerarca del sujeto pasivo infractor para que sancione directamente al servidor público o al empleado encausado, así como al superior rebelde $^{12}$.

Si el funcionario rebelde fuera el jerarca, el expediente será enviado a la Presidencia de la República o al órgano que corresponda para que resuelva lo pertinente ${ }^{13}$.

La autonomía universitaria, consagrada en el artículo 84 de la Constitución Política, impide absolutamente a la Presidencia de la República interferir en el gobierno, en la estructura, en las decisiones o en las actividades universitarias y, con mucho mayor razón, le impide aplicar sanciones o destituciones a los 
funcionarios universitarios. Como la Asamblea Institucional Representativa es la más alta autoridad en el Instituto Tecnológico de Costa Rica, ${ }^{14}$ no existe posibilidad de que algún otro órgano o ente pudiera obligarla a adoptar determinado comportamiento.

Por otra parte, la posibilidad de establecer recursos ordinarios contra resoluciones dictadas por funcionarios de la Contraloría General de la República no convierte a esta en un tribunal administrativo, ni dota al Despacho Contralor de posición jerárquica sobre las Universidades estatales, ni le confiere atribuciones para dictar órdenes, ni criterios vinculantes, así como tampoco para suplantar en forma alguna a las autoridades universitarias en la toma de decisiones.

Las órdenes precisas dirigidas por la Gerente del Área de Servicios Sociales de la Contraloría General al Presidente de la Asamblea Institucional Representativa pueden ser desglosadas de la siguiente manera: 
1) convocar a sesión extraordinaria de Asamblea Institucional Representativa dentro de los tres días siguientes;

2) celebrar sesión extraordinaria antes del 16 de diciembre de 2010;

3) en tal sesión, como punto único de la agenda, deberá conocerse y aprobarse la prohibición del desempeño simultáneo de funciones de Coordinador General y Coordinador de Proyecto por parte de una misma persona;

4) enviar la convocatoria a la Contraloría General antes del 30 de noviembre de 2010;

5) convocar a sesiones ordinarias de la Asamblea Institucional Representativa para marzo y setiembre de 2011 e incluir en la agenda el conocimiento y la aprobación de la modificación al Reglamento para la Vinculación Remunerada Externa, para definir las funciones del Coordinador General y del Coordinador de Proyecto y para prohibir el desempeño simultáneo de ambos puestos por una misma persona; 
6) enviar a la Contraloría General la convocatoria y la agenda para la primera sesión ordinaria, antes del 15 de febrero de 2011; y

7) antes del 16 de agosto de 2011, enviar a la Contraloría General la convocatoria y la agenda para la segunda sesión ordinaria.

A la Asamblea Institucional Representativa, la Gerente de Área de Servicios Sociales ordenó de modo terminante lo siguiente:

1) conocer y aprobar la prohibición del desempeño simultáneo de funciones de Coordinador General y Coordinador de Proyecto por parte de una misma persona; $\mathrm{y}$

2) conocer y la aprobar la modificación al Reglamento para la Vinculación Remunerada Externa, para definir las funciones del Coordinador General y del Coordinador de Proyecto y para prohibir el desempeño simultáneo de ambos puestos por la misma persona. 
Resulta inconcebible y descabellado que una funcionaria de la Contraloría General desconozca la plena capacidad jurídica que tiene la Institución para darse su propio gobierno y la plena capacidad jurídica que tiene para darse su propia organización. No solo desconoce el contenido del artículo 84 de la Constitución Política, sino que ilegítimamente se arroga, ella misma, tales facultades de gobierno y de organización, interfiriendo en ellas y atribuyéndoselas, y en consecuencia, desplazando a quienes sí tienen asignadas de modo legítimo tales atribuciones y competencias.

La convocatoria a sesiones ordinarias o extraordinarias de la Asamblea Institucional Representativa, que ha hecho esta funcionaria, es un acto absolutamente nulo, además de grotesco y ridículo. Lo mismo cabe decir, y con mayor motivo, respecto a la convocatoria indirecta - mediante la imperativa orden dirigida por ella al Presidente del órgano- - Convocar a sesiones y fijar los puntos de la agenda son actividades propias de gobierno, de gobierno universitario en este caso, y jamás podrían ser consideradas sensatamente como atribuciones de quien — como funcionaria de la Contraloría General — a lo sumo podría ejercer algunas funciones de simple fiscalización o de mera vigilancia. 
La redacción de la agenda de cualquiera de las sesiones que hubiera formulado esta funcionaria - ajena y extraña al Instituto Tecnológico - habría corrido la misma suerte de nulidad, ridiculez y extravagancia que la convocatoria efectuada por ella. Del mismo modo, ella no podría pretender actuar indirectamente, mediante órdenes giradas al Presidente de este alto órgano de la institución.

Esta misma funcionaria también pretendió que la Asamblea Institucional Representativa estaba obligada a prohibir el desempeño simultáneo de funciones de Coordinador General y de Coordinador de Proyecto. ¿Cómo puede quedar obligada a hacer esto una Asamblea Institucional?, ¿quién le otorgó atribuciones a esta funcionaria - de tercera o menor categoría - para someter la Asamblea a su voluntad? Si ella hubiera poseído tanto poder, ¿por qué no estableció la prohibición ella, por sí misma? Nuevamente afloran la nulidad, lo grotesco, lo ridículo y lo arbitrario. No se preocupó esta funcionaria por averiguar si la Asamblea Institucional tenía o no facultades para establecer una prohibición tal, por simple acuerdo. De la lectura del Estatuto Orgánico no se desprende que la Asamblea Institucional Plebiscitaria tenga atribuciones o competencias para ello ${ }^{15}$. Para que una prohibición pudiera tener efectos, debería estar contenida en un texto normativo, ya fuera en un reglamento institucional o en el Estatuto Orgánico y estas normas jurídicas tienen un procedimiento especial para su reforma. 
La Asamblea Institucional Representativa carece de facultades para dictar una prohibición general. Tampoco posee facultades para modificar reglamentos. Aunque este alto órgano estuviera sujeto a las órdenes de la funcionaria de Servicios Sociales de la Contraloría - que no lo está—, ocurre que no podría modificar el Reglamento para la Vinculación Remunerada Externa, con el propósito de definir las funciones del Coordinador General y del Coordinador de Proyecto y para prohibir el desempeño simultáneo de ambos puestos por una misma persona, como le fue ordenado por la citada funcionaria. La competencia para aprobar, promulgar y modificar los reglamentos generales necesarios para el funcionamiento del Instituto, así como los suyos propios [...] corresponde al Consejo Institucional. ${ }^{16}$

La Constitución Política otorga a las Universidades públicas independencia en sus funciones, en todas sus funciones, incluyendo las funciones de gobierno y de organización y, además, para complementar tal independencia, les otorga plena capacidad jurídica para darse su propio gobierno y su propia organización. 
El Instituto Tecnológico de Costa Rica —institución universitaria estatal - interpuso una acción de inconstitucionalidad contra los citados oficios DFOE-SOC-1196 del 29 de noviembre y DFOE-SOC-IF-752010, emitidos por una mencionada funcionaria de Servicios Sociales de la Contraloría General de la República, por considerar que violaban las disposiciones constitucionales que resguardan la autonomía universitaria.

\section{Una acción de} inconstitucionalidad

Inicialmente el Instituto Tecnológico había interpuesto un recurso de amparo contra la comunicación recibida de la Contraloría General. En el expediente respectivo, la Sala Constitucional dio un plazo para que se interpusiese una acción de inconstitucionalidad. Esta acción fue presentada. Ante reparos de la Contraloría General, la Sala Constitucional indicó que no era procedente la vía de amparo debido a que no se estaba discutiendo la infracción a derechos fundamentales, sino que correspondía al ámbito de la inconstitucionalidad, por reclamarse contra la lesión a competencias constitucionalmente establecidas para una institución de educación superior estatal ${ }^{17}$.

A continuación se hacen algunos comentarios sobre la resolución de la Sala Constitucional número 9215 del año $2012^{18}$, que rechazó una acción de inconstitucionalidad presentada por el Instituto Tecnológico de Costa Rica contra algunas órdenes giradas por la Contraloría General ${ }^{19}$. 
Las importantes atribuciones y facultades - constitucionales y legales - que competen a la Contraloría General con respecto a la hacienda pública no pueden desconocer ninguno de los ámbitos o aspectos de la autonomía otorgada por la Constitución Política a las Universidades estatales ${ }^{20}$.

En criterio del Instituto Tecnológico, tales órdenes al Directorio de la Asamblea Institucional Representativa, máxima autoridad institucional, para convocar a sesión de Asamblea, dejan de lado la independencia para el desempeño de sus funciones que establece el artículo 84 constitucional a favor de las Universidades y la posibilidad de darse su organización y gobierno propios. Al mismo tiempo, infringe el contenido de la normativa interna universitaria en cuanto a plazos, calendarios y otros elementos.

De igual forma, el Instituto Tecnológico alegó que la orden de adoptar inmediatamente un acuerdo para prohibir el desempeño simultáneo de funciones de Coordinador General y Coordinador de Proyecto por una misma persona, que debía dictarse en la próxima sesión extraordinaria y comunicarse su cumplimiento a la Contraloría a más tardar el 17 de diciembre de 2010, así como la orden a la Asamblea de aprobar una modificación reglamentaria relacionada con el tema de las coordinaciones generales y las coordinaciones de proyectos específicos, no solo constituyen una intromisión en la organización de la Universidad, que impide la debida discusión y deliberación 
de la Asamblea como ente plural y democrático, sino que también transgrede la normativa interna, ya que el Reglamento vigente contempla una fórmula que, en criterio de dicha Institución, lograba satisfacer de forma suficiente las exigencias requeridas sobre control interno. En el informe de la Contraloría se hizo caso omiso de ello y se ordenó adoptar una estructura particular que cercena el poder de auto organización concedido por la Constitución a la Institución.

En el Considerando III de la mencionada resolución número 9215, la Sala Constitucional señaló que:

[...] no existe duda para [las] partes ni tampoco para esta Sala,

Rango constitucional o rango legal de las normas jurídicas respecto del contenido de competencia que la Constitución Política costarricense ha atribuido a la Contraloría General de la República, consistente en vigilar la forma en que las instituciones públicas disponen de los fondos públicos, con la finalidad de asegurar a la sociedad que la disposición de tales dineros sea correcta, es decir, acorde con las normas y principios constitucionales y legales establecidos para el manejo de la Hacienda Pública [...] 
La Constitución Política, sin dejar margen a duda alguna, establece que a la Contraloría General, entre otras cosas, le compete vigilar la hacienda pública ${ }^{21}$ y examinar, glosar y fenecer las cuentas del Estado y de los funcionarios públicos (artículos 183 y 184). Pero la Constitución Política no dice —como erróneamente lo afirma la Sala Constitucional — que tal vigilancia verse sobre la conformidad de la disposición de los fondos públicos con las normas y principios legales establecidos para el manejo de la hacienda pública.

Se podría admitir que la Constitución Política está presuponiendo una vigilancia sobre la correcta y responsable utilización de la hacienda pública, pero es inadmisible que junto a la función de vigilancia (constitucionalmente establecida) se coloque arbitrariamente una función de control como si estuviera estipulada por la carta magna.

No se trata de que la Contraloría General, al vigilar, constate en igual forma e indiscriminadamente la conformidad con normas y principios legales establecidos, en general, para todos los órganos y entes públicos, sino de que constate la conformidad con las normas y los principios legales aplicables a las Universidades estatales, conforme a la naturaleza jurídica que les ha sido dotada por la Constitución Política. 
Resulta absolutamente inaceptable que, so pretexto de establecerse normas y principios legales respecto a la vigilancia de la hacienda pública, se menoscaben aspectos esenciales de la autonomía universitaria, tales como la plena capacidad jurídica que poseen las Universidades estatales al tenor de la Constitución Política para organizarse y para gobernarse.

Aunque el inciso $5^{\circ}$ del artículo 184 de la Constitución amplía los deberes y atribuciones de la Contraloría General a [...] Las demás que esta Constitución o las leyes le asignen, no significa ello que estas otras normas de carácter pura y simplemente legal adquieran rango de disposiciones constitucionales. En el texto restante de la Constitución Política no existen otras normas que otorguen funciones adicionales a la Contraloría General, con excepción de lo dispuesto por los artículos 179, 180 y 181, ninguno de los cuales se refiere a control.

Es necesario distinguir y separar las normas de rango constitucional de otras normas de rango puramente legal. Los Magistrados de la Sala Constitucional confunden ambos tipos de normas y a todo ese confuso conjunto - indebidamente mezclado - le otorgan un único e idéntico rango constitucional. Las normas superiores de orden constitucional no pueden entremezclarse indistintamente con las normas inferiores de naturaleza legal. La Sala Constitucional no puede “constitucionalizar" normas legales ordinarias o comunes. 
La Contraloría General posee funciones o atribuciones otorgadas directamente por la Constitución Política, que tienen igual rango jurídico que el de la autonomía universitaria. La Universidad estatal, no obstante su autonomía, está sujeta a la vigilancia de la Contraloría General y a la rendición de cuentas, que sí están contempladas en la Carta política fundamental.

La Contraloría General, además, posee muchas otras funciones o atribuciones provenientes de leyes ordinarias, subordinadas a la Constitución, que no están ubicadas sobre la autonomía universitaria constitucional. Al contrario: tales normas legales están subordinadas a las normas de rango constitucional, que incluyen — claro está— las normas constitucionales sobre autonomía universitaria. Estas otras funciones o atribuciones de naturaleza legal común u ordinaria de la Contraloría General no pueden restringir la autonomía universitaria, ni la facultan para interferir en ella. Ninguno de los aspectos o facetas integrantes de la autonomía universitaria —a los que se hará referencia más adelante - puede resultar disminuido, condicionado o restringido por las funciones o atribuciones de la Contraloría General provenientes de leyes comunes u ordinarias.

Las presentes consideraciones, aunque elementales, son muy importantes al analizar y comparar el ámbito de competencia — de conformidad con lo estipulado por la Constitución Política - que corresponde a las Universidades estatales y el que se asigna a la Contraloría General. 
Los deberes y funciones atribuidos por las normas legales a la Contraloría General de la República (subordinadas a la Constitución Política) no le otorgan facultad alguna para interferir en los ámbitos de competencia universitarios otorgados por disposición constitucional expresa.

Las atribuciones de la Contraloría General que provengan, no directamente de la Constitución Política, sino de normas de rango legal, tales como la Ley Orgánica de la Contraloría General de la República o la Ley General de Control Interno, no disminuyen ni mucho menos prevalecen sobre las normas constitucionales (y por ello superiores) referidas a las Universidades estatales.

Si la Constitución Política, en determinados artículos, hace referencia a la ley, esto no significa que tal ley adquiera carácter de norma constitucional, ni de lo que se ha dado en llamar derecho de la Constitución ${ }^{22}$. Los deberes y funciones de la Contraloría General, provenientes de leyes, no son deberes ni funciones de rango constitucional, sino de rango legal y, por tanto, no pueden prevalecer sobre normas de la Constitución Política, como las que consagran la autonomía universitaria. 
No se trata de un galimatías, ni de un juego de palabras. Controlar no es lo mismo que contralorear. Al afirmarse que a la Contraloría General de la República le corresponde, por su propia naturaleza y primordialmente, el ejercicio del control, se está incurriendo en un lamentable error.

La función de controlar no equivale a la función de contralor. Son palabras con una escritura parecida, pero con un significado diferente.

La voz contraloría es un término americano (proveniente de contralor) y significa, en una única acepción, órgano encargado de examinar la legalidad y corrección de los gastos públicos ${ }^{23}$. La expresión contralor, de la cual procede, significa, en su tercera acepción, funcionario encargado de examinar las cuentas y la legalidad de los gastos oficiales ${ }^{24 .}$

El término control (del francés contrôle), por su parte, en una primera acepción significa comprobación, inspección, fiscalización, intervención; como segundo significado es dominio, mando, preponderancia; y como tercer concepto, oficina, despacho, dependencia, etc., donde se controla ${ }^{25}$.

\section{Controlar no es lo mismo que contralorear}


La función propia y específica de la Contraloría General de la República es la de contralorear, no la de controlar. Esto no constituye una disquisición baladí, ni una mera cuestión terminológica o lingüística. Tal distinción tiene importantísimas consecuencias jurídicas.

La Constitución Política costarricense, a la Contraloría General de la República, que es una institución auxiliar de la Asamblea Legislativa, le otorga funciones específicas de vigilancia y de fiscalización, ${ }^{26}$ es decir, de contralorear, no de controlar. Se trata fundamentalmente de funciones de vigilancia de la hacienda pública y de fiscalización de la ejecución y liquidación de los presupuestos ordinarios y extraordinarios de la República. También le compete examinar, aprobar o improbar los presupuestos de las Municipalidades e instituciones autónomas, y fiscalizar su ejecución y liquidación. Además, tiene la misión de examinar, glosar y fenecer las cuentas de las instituciones del Estado y de los funcionarios públicos. Las funciones otorgadas por la Constitución Política se relacionan, todas, con la fiscalización y la vigilancia, no con el control.

También establece la Carta Fundamental que son atribuciones de la Contraloría las demás que esta Constitución o las leyes le asignen. ${ }^{27}$ Tal como se expuso antes, algunas leyes otorgan a la Contraloría atribuciones de control, que no se funden ni confunden con las atribuciones de contralor. 
Las facultades de control que posee la Contraloría General le han sido atribuidas por leyes ordinarias. ${ }^{28}$ Estas atribuciones o competencias relacionadas con el control no poseen rango constitucional, ni pueden ser asimiladas a las atribuciones establecidas directamente por la Constitución Política. Las fuentes de las que emanan estas variadas atribuciones no son equivalentes. Una fuente es la Constitución y otra, la ley ordinaria.

A las Universidades estatales, por el solo hecho de ser instituciones públicas, no se les puede incorporar — de modo indiscriminado e indistinto - dentro del conjunto general constituido por todos los órganos y entes públicos, desconociéndose o ignorándose sus notas esenciales o características. A las

La autonomía universitaria no es una situación de excepción Universidades estatales no se les puede aplicar, a ciegas, cualquier ley, cualquier decreto o cualquier directriz gubernamental.

No se trata de que las Universidades estatales pretendan ostentar un régimen excepcional frente a las demás instituciones públicas, como si todas fueran iguales, como si todas ostentaran una naturaleza jurídica idéntica, como si todas estuvieran vinculadas a un único ordenamiento jurídico. La naturaleza jurídica peculiar de la Universidad estatal resultante, tanto de la esencia propia de la Universidad, como del especial régimen jurídico — acorde con esa esencia propia- establecido en la Constitución Política, impide que se le pueda considerar con otra institución pública, sin más, o como una institución pública común inexorablemente sometida a todas las normas legales y reglamentarias. 
Si se tratara de un régimen legal excepcional, sería necesario que en cada ley o reglamento se estipulara — de modo expreso- que esas normas no fueran aplicables a la Universidad estatal. Tendría que existir una razón suficiente para establecer la situación de excepción. Las leyes son obligatorias y no cabe alegar su desconocimiento. ${ }^{29}$ Todas las personas físicas son iguales ante las leyes y es inadmisible cualquier discriminación contraria a la dignidad humana. ${ }^{30}$ Con respecto a las personas jurídicas no puede predicarse la misma igualdad. Los regímenes de Derecho privado y de Derecho público son diferentes. Y, dentro del Derecho público, no todas las instituciones son iguales, ni a todas se les aplican las leyes en forma idéntica. A instituciones desiguales no se les pueden aplicar todas las mismas disposiciones.

El régimen de privilegio estriba en la exención de una obligación o ventaja exclusiva o especial que goza alguien por concesión de su superior o por determinada circunstancia propia. ${ }^{31}$ En el caso de la Universidad estatal, las ventajas especiales de que goza, provienen — no de concesión graciosa o temporal de algún ente superior - sino de sus circunstancias propias: peculiar esencia y especial régimen jurídico. No se trata de privilegios. 
Por encima de la Universidad estatal costarricense no existe un solo ente u órgano superior al que se encuentre subordinada. Está supeditada a la Constitución Política, a sus normas y principios, pero no a ente u órgano alguno. En el organigrama del Estado costarricense, en el nivel más alto se encuentran los tres Poderes de la República y también el Tribunal Supremo de Elecciones. La Universidad estatal, con gobierno y organización propios, no se encuentra subordinada a ninguno de esos Poderes, ni al Tribunal electoral, en el ámbito de sus funciones ${ }^{32}$ y se ubica, por tanto, en ese mismo nivel supremo. Esta afirmación podría parecer exagerada o presuntuosa, pero se ciñe estrictamente a la realidad jurídica y al especial régimen jurídico aplicable.

Precisamente, la autonomía universitaria constitucionalmente conferida y el más alto grado a nivel jerárquico ocupado por la Universidad estatal en el organigrama del Estado, hacen que la institución universitaria sea partícipe activa directa de alguna porción importante de la soberanía $a^{33}$, del gobierno, o de la potestad pública costarricenses. Así también corresponde, dentro de su esfera de competencia, al Poder Ejecutivo, a la Asamblea Legislativa, a los tribunales de la Corte Suprema de Justicia y al Tribunal Supremo de Elecciones. 
La autonomía universitaria, calificada como especial, es completa y distinta de la autonomía propia de los entes descentralizados (o instituciones autónomas) y significa que las Universidades estatales, como lo indica una conocida resolución de la Sala Constitucional,

[...] están fuera de la dirección del Poder Ejecutivo y de su jerarquía, que cuentan con todas las facultades y poderes administrativos necesarios para llevar adelante el fin especial que legítimamente se les ha encomendado, que pueden autodeterminarse, en el sentido de que están posibilitadas para establecer sus planes, programas, presupuestos, organización interna y estructurar su gobierno propio. Tienen poder reglamentario (autónomo y de ejecución): pueden autoestructurarse, repartir sus competencias dentro del ámbito interno del ente, desconcentrarse en lo jurídicamente posible y lícito, regular el servicio que prestan, y decidir libremente sobre su personal (...) Son estas las modalidades administrativa, política, organizativa y financiera de la autonomía que corresponde a las universidades públicas. La autonomía universitaria tiene como finalidad, procurar al ente todas las condiciones jurídicas necesarias para que lleve a cabo con independencia su misión de cultura y educación superiores $[\ldots]^{34}$ 
En esa misma resolución fueron analizados los límites a la potestad legislativa en relación con la autonomía universitaria. A la Asamblea Legislativa

[...] le está vedado imposibilitar, restar o disminuir a esas instituciones, aquellas potestades que les son necesarias para cumplir su correspondiente finalidad y que conforman su propia Autonomía. Es decir, para expresarlo en los términos de cierta doctrina relevante, esos entes tienen la titularidad y el ejercicio inicial, independiente e irrestricto de todas las potestades administrativas y docentes para el cumplimiento de su especialización material, sin que esto pueda ser menoscabado por la Ley [... $]^{35}$

A esto - potestades administrativas y docentes - deben agregarse todos los restantes aspectos o facetas de la autonomía universitaria, que se expondrán más adelante y que resultan inseparables unos de otros, constituyendo un todo armónico e indivisible que no se puede fraccionar.

Pareciera existir una antinomia entre los artículos 84 y 88 de la Constitución Política, en cuanto el primero otorga independencia en sus funciones, y en tanto el segundo admite la posibilidad de intervención de la Asamblea Legislativa en las materias puestas bajo la competencia de la Universidad. La independencia conferida en tema de funciones, materias o competencias 
atribuidas a la Universidad es tan amplia que, en efecto, impide que se configure tal antinomia. La autonomía universitaria no puede ser restringida, ni condicionada por normas legales emanadas de la Asamblea Legislativa. La expresión materias puestas bajo la competencia de la Universidad se refiere a materias o funciones adicionales a las que por su propia naturaleza competen a la Universidad estatal. Estas funciones adicionales tendrían que ser objeto de aceptación libre y voluntaria de la Universidad estatal. No es posible que por ley se le impongan funciones adicionales a estas instituciones, ni que se desnaturalicen sus funciones peculiares y propias.

La autonomía universitaria, dentro de sus justos límites, impide la intervención de la Asamblea Legislativa en cualquiera de sus mencionados aspectos o facetas, que serán examinados a continuación. No se trata de un régimen de excepción, ni de privilegio, sino de la necesaria y legítima aplicación de especiales disposiciones de la Constitución Política. Más que de inmunidad universitaria ante el Poder Legislativo pareciera más propio hablar de incompetencia legislativa en el ámbito de la autonomía universitaria. ${ }^{36}$ No se trata de que la autonomía universitaria constituya una excepción a la aplicación de una regla general, sino de que la regla general no es aplicable a la Universidad debido al régimen jurídico peculiar que la regula. 
La autonomía universitaria no es consecuencia de un régimen de excepción a la aplicación del ordenamiento jurídico costarricense, ni de privilegio alguno, sino que es el resultado del ordenamiento jurídico aplicable conforme a la naturaleza de esa autonomía.

Si a una institución, como lo es la Universidad estatal costarricense, la Constitución Política - y no una simple ley— le ha conferido una naturaleza jurídica peculiar, notablemente diferente de la naturaleza de las restantes instituciones públicas, tanto centralizadas como autónomas o descentralizadas, ello significa que no puede sufrir un trato igualitario y que no puede ser incluida dentro de un conjunto genérico de instituciones públicas, ni tratársele como si fuera una institución pública más, igual o similar a las restantes. ${ }^{37}$

La Contraloría General, la Asamblea Legislativa, el Poder Ejecutivo, la Sala Constitucional y los otros Tribunales judiciales, la Procuraduría General y cualquier otro órgano o ente público o privado, no pueden desconocer la naturaleza jurídica propia de las Universidades estatales costarricenses. Esta naturaleza jurídica es peculiar y es muy distinta y diferente a la naturaleza jurídica correspondiente al resto de los entes y órganos comprendidos dentro de la Administración Pública o, en general, en el sector público. 
$\mathrm{Al}$ reconocer y al respetar la naturaleza jurídica peculiar de las Universidades estatales costarricenses —naturaleza jurídica conferida por la Constitución Política de modo expreso- no se les está otorgando privilegios ni prerrogativas irritantes o ilegítimos. Precisamente el desconocimiento de esa naturaleza jurídica propia de las Universidades estatales por parte de la Contraloría General constituye un irrespeto a las instituciones universitarias y también un irrespeto y una violación a la Constitución Política.

El irrespeto a la Universidad y la violación a la Constitución Política, por parte de la Contraloría General de la República, no se subsanan con el pronunciamiento de la Sala Constitucional contenido en la resolución comentada. Continúa existiendo inconstitucionalidad a pesar de lo que haya expresado este alto tribunal de Justicia.

La Constitución Política, en sus artículos 84 y 85, consagra la autonomía de las Universidades estatales. La autonomía universitaria comprende, en forma interrelacionada, armónica e indivisible, varios aspectos o facetas:

\section{Distintas facetas de la autonomía universitaria}

1) Independencia de funciones. La Universidad no posee dependencia o subordinación respecto de ningún órgano o ente, público o privado, nacional ni internacional. La Universidad ejerce y cumple con todas sus funciones con absoluta independencia, con absoluta libertad. Las funciones las define la propia Universidad, tomando en cuenta el bien 
común y las necesidades propias del país. Se trata de una independencia y de una libertad responsable, orientada hacia la consecución de los fines universitarios de cultura superior. Nadie puede, por tanto, girarle órdenes o instrucciones, ni prohibirle actividades o conductas, ni imponerle condicionamientos o restricciones. La independencia funcional universitaria no equivale a la independencia administrativa propia de las instituciones autónomas (artículo 188 de la Constitución Política), como tampoco a la relativa independencia funcional de los órganos desconcentrados, de las instituciones descentralizadas, ni de los órganos dotados de personería jurídica instrumental. La independencia funcional universitaria debe verse necesariamente en relación con todos los otros aspectos o facetas de la autonomía, que resultan interdependientes e inseparables entre sí. La independencia de funciones no puede ser analizada en forma aislada o segregada del resto de estos aspectos o facetas.

2) Plena capacidad jurídica para adquirir derechos y contraer obligaciones.

La Universidad ostenta una capacidad jurídica sin restricciones, es decir, completa, para contratar, es decir, para adquirir bienes y servicios, para obligarse, para relacionarse jurídicamente con todo tipo de personas, físicas o jurídicas, públicas o privadas, para utilizar todos los medios que estime necesarios y convenientes para la consecución de sus fines. La Universidad no requiere de previas autorizaciones de la Contraloría General, ni de refrendos, para ejercer su capacidad jurídica de amplia e irrestricta contratación. La Universidad, con esta capacidad jurídica plena, puede 
constituir personas jurídicas y formar parte de ellas, conforme a las normas legales generales aplicables a los sujetos de derecho y privado.

3) Plena capacidad jurídica para organizarse. Compete exclusivamente a la Universidad darse su propia organización: establecer órganos, unidades, dependencias; crear competencias y atribuir responsabilidades; definir su estructura orgánica; establecer sus carreras y programas académicos, orientar sus investigaciones, desarrollar la acción social que estime conveniente, establecer relaciones de interés para la Institución con entes externos, etc. Esta capacidad jurídica también es completa y no precisa de autorización ni de aprobación de nadie. La capacidad jurídica de auto organización excluye toda potestad legislativa ${ }^{38}$ y por consiguiente también excluye toda potestad del Poder Ejecutivo, de la Procuraduría General o de la Contraloría General. La forma y el sistema de control interno que estime conveniente utilizar la Universidad es una decisión propia y, desde luego, responsable. La Contraloría General carece de facultades constitucionales para ordenarle a la Universidad la adopción de determinados procesos de control interno y, asimismo y en forma absoluta, carece de autoridad y de potestad para ordenarle que sea convocado determinado órgano universitario, ni que a este órgano universitario se le imponga obligatoriamente determinada conducta, ni que se sujete a determinados plazos para obedecer estas 
órdenes administrativas. Esta facultad o capacidad plena de organización comprende también la elaboración y aprobación de normas estatutarias, reglamentos, planes, proyectos y presupuestos. No existe disposición alguna en la Constitución Política que obligue a la Universidad a que sus presupuestos deban ser aprobados por la Contraloría General. La capacidad jurídica plena universitaria para organizarse se aplica a la totalidad de su estructura y de sus funciones. ${ }^{39}$

4) Plena capacidad jurídica para gobernarse. El gobierno universitario no puede estar mediatizado, ni subordinado, ni supeditado a órganos, entes, funcionarios, de carácter público o de carácter privado. La Universidad se da su propio gobierno. Se trata de una autonomía política por la cual tiene plena capacidad para autodirigirse, para autogobernarse, para dictarse a sí misma sus propios objetivos. ${ }^{40} \mathrm{Se}$ podría afirmar que esta autonomía política constituye una expresión de la soberanía o de algo muy cercano a ella. Debe tenerse en cuenta que las Universidades estatales forman parte del Estado pero no son pertenencia del Estado (ni del Gobierno). Y así como el juez al dictar sentencia actúa como Estado, esto es, no en representación del Estado sino como Estado actuante, personificado en el funcionario, ${ }^{41}$ lo mismo que la Universidad: institución estatal de cultura superior que, al actuar, lo hace como Estado costarricense, dentro de su propia 
esfera de competencia. Del mismo modo que al juez se le atribuye determinada expresión de la soberanía, también a la Universidad y con mayor fundamento. La Universidad no reclama extraterritorialidad, aunque sí reclama libertad. En tiempos de mundialización, de facilidad en las comunicaciones, va perdiendo importancia la noción de territorio e incluso la de soberanía nacional. La Universidad no está circunscrita a una delimitación geográfica. Poco a poco la Universidad va recuperando el carácter universal que tuvo en sus orígenes.

5) Patrimonio propio o hacienda universitaria. La libertad, la independencia y la plena capacidad jurídica universitarias no podrían ejercitarse sin la titularidad de un patrimonio propio, suficiente, para el cumplimiento de las funciones universitarias. Este elemento, al igual que los otros aspectos o facetas, es inescindible e inseparable de los restantes. Una libertad universitaria sin patrimonio propio significaría dependencia o condicionamiento de todas sus actividades, ya fuera a lo que el Poder Ejecutivo impusiera o a lo que la empresa privada financiara como actividades de su interés y provecho. Constituye obligación del Estado dotar de patrimonio propio suficiente a cada una de las Universidades estatales. La administración y disposición de este patrimonio propio 
constituye competencia y responsabilidad exclusiva de la Universidad. Ningún órgano o ente ajeno a la Universidad puede interferir en estas funciones de carácter patrimonial. Aunque resulte obvio, es necesario indicar que el patrimonio de la Universidad pertenece a la propia Universidad, aunque la hacienda universitaria incorpore determinados bienes públicos. La administración y disposición de todos los bienes patrimoniales universitarios compete única y exclusivamente a la Universidad, en forma directa e inmediata. La Universidad ostenta plena capacidad jurídica para contratar y no requiere de autorizaciones previas, ni de aprobaciones posteriores del Poder Ejecutivo, de la Asamblea Legislativa, ni de la Contraloría General. La naturaleza jurídica pública del patrimonio universitario no la subsume - de modo indiferenciadoen la hacienda pública. A la hacienda pública, en general, se le aplican determinadas disposiciones legales. Tales disposiciones legales no pueden restringir, disminuir o ignorar la existencia de los peculiares aspectos o facetas de la autonomía universitaria, establecida por una fuente jurídica de rango superior: la Constitución Política. A la hacienda universitaria no se le puede dar un tratamiento que la abstraiga o separe de las notas características propias de la autonomía universitaria constitucional. Todos sus aspectos o facetas, como ya se ha dicho, son inseparables, armónicos e inescindibles. La hacienda universitaria, el patrimonio universitario, no se confunde con la hacienda pública. La hacienda universitaria o patrimonio universitario pertenece a la Universidad estatal, no al Estado, ni al Gobierno. El Estado no puede 
disponer de la hacienda universitaria en forma alguna. El Estado tampoco es dueño de la Universidad, que es un ente con personería jurídica independiente y con plena capacidad jurídica. No ocurre esto con las instituciones autónomas, los Bancos estatales por ejemplo, que sí pertenecen al Estado y son propiedad suya.

6) Financiación estatal. Otro aspecto de la autonomía universitaria es la obligación estatal de financiación. Además de dotar ${ }^{42}$ de patrimonio propio a cada Universidad estatal, el Estado debe crearles rentas propias, independientemente de las originadas en estas instituciones y debe mantener un fondo especial para el financiamiento de la educación superior (FEES). La independencia o autonomía económica o financiera de la Universidad fue uno de los aspectos que más se destacó por los Diputados de la Asamblea Nacional Constituyente en el año 1949 y fue impulsada y defendida especialmente por el Diputado constituyente Fernando Baudrit Solera, quien fungía en ese entonces como Rector de la Universidad de Costa Rica. ${ }^{43}$ Uno de los representantes expresó que [...] la Universidad no podrá llevar a cabo su alta misión, gozar de plena independencia, si no cuenta con los medios económicos indispensables. Para que una institución goce de libertad, es necesario que esté asentada sobre una sólida base económica $[\ldots]^{44}$. Otro de ellos expuso: [...] no es posible condenar 
a nuestra Universidad a acudir año con año a los políticos, en demanda de rentas. Si así fuera, la estaríamos condenando a una asfixia segura, ya que, al no contar con la autonomía económica indispensable, la Universidad estará a merced de los políticos, según que les satisfaga o no el ambiente universitario. En esta situación, preferible sería cerrarla, si va a estar a merced de los vaivenes de la politiquería. $^{45}$

Antes de que fuese creada la Universidad de Costa Rica, por gestión del Gobierno de la República vino al país el profesor chileno Luis Galdames, quien luego de analizar la realidad dejó escrito lo siguiente:

En lo económico, la autonomía consiste en la libre distribución de los fondos que el Estado le asigne a la Universidad globalmente, en los presupuestos de cada año, o que le pueda asignar con arreglo a leyes especiales. En este ejercicio financiero, la única restricción que la ley no puede menos de adoptar es la relativa a la rendición de cuentas ante la oficina contralora de todas las inversiones fiscales. Pero, justamente, es este aspecto de la autonomía el que mayor peligro ofrece para las labores y la estabilidad de la corporación, el que la puede sumir en una permanente zozobra. // Si sus rumbos no agradaran a la autoridad política, no sería raro que el enojo de ésta se manifestase con la restricción de recursos; y en tal caso, la autonomía entera quedaría en el 
papel. Por eso se tiende a crear para la Universidad un fondo propio, que a la larga exonere al gobierno de la obligación de consultarle sumas globales en los presupuestos de cada año [...] ${ }^{46}$

Cada uno de los aspectos o facetas de la autonomía universitaria resulta necesariamente vinculado a las restantes. Se encuentran interconectados y se presuponen unos a otros, en forma ineludible. La imposición de una restricción a la capacidad de autoorganización repercute en el gobierno, en las funciones, en la dimensión financiera y en la hacienda universitaria. Exactamente lo mismo ocurre con una lesión a la capacidad jurídica plena de gobierno, de administración o de contratación. Y así ocurre con cada uno de los aspectos o facetas de la autonomía universitaria. Por este motivo, resultan inseparables unos de otros, constituyendo un todo indivisible que no puede ser objeto de fraccionamiento. Los aspectos o facetas de la autonomía universitaria deben ser analizados, siempre, en su conjunto. ${ }^{47}$

La señora Procuradora General de la República, al referirse a la acción de inconstitucionalidad, consideró

\section{La vigilancia de la hacienda universitaria}

[...] que no se está cuestionando la potestad de la Contraloría General de la República para fiscalizar el control interno ejercido por el Instituto Tecnológico en los temas objeto del informe, sino más bien la obligación de acatar las normas técnicas que emita la Contraloría y en particular 
las disposiciones concretas que en uso de esa facultad se emitieron en el caso concreto por entender que afectan la autonomía universitaria [...]

En efecto, las facultades de vigilancia de la hacienda pública atribuidas a la Contraloría General por la Constitución Política ${ }^{48}$ no fueron objetadas por la Institución accionante, ni han sido cuestionadas por las otras Universidades estatales. Se trata de atribuciones legítimas con asidero en la Constitución. Son únicamente facultades de fiscalización (o de vigilancia). Ambos términos vigilancia y fiscalización - tienen un significado semejante.

La labor de vigilancia no permite al vigilante girar órdenes al vigilado, ni sustituirlo en sus funciones, ni en sus decisiones. El vigilante no es superior jerárquico del vigilado. Vigilar es velar sobre alguien o algo, o atender exacta y cuidadosamente a él o a ello ${ }^{49}$ y velar es hacer centinela o guardia por la noche $e^{50}$.

Las atribuciones de vigilancia no pueden ser extralimitadas. Un guardia o un centinela cuidan desde fuera: no se entrometen en las funciones. Vigilar es velar o atender cuidadosamente algo. No es "regular", ni reglamentar. No es interferir en la gestión. No es ordenar que se ejecute determinado acto. No es asumir la posición de superior jerárquico. No es ejercer potestad disciplinaria 
alguna. Tampoco es —obsérvese con detenimiento - ejercer acciones de control, de mando, de intervención. Desde luego, la vigilancia no permite tampoco al vigilante que sustituya o suplante al titular del patrimonio universitario. La Contraloría General no es administradora de la hacienda universitaria, ni tiene facultad alguna para disponer de ella, ni para inmiscuirse en el gobierno, en la organización, ni en la administración, ni en las funciones universitarias. $^{51}$

A los fiscales de las sociedades anónimas les compete la vigilancia de la entidad y carecen de funciones administrativas y de representación de la sociedad. ${ }^{52}$ A quienes se les encargue una labor de auditoría —interna o externa - nunca se les atribuye facultades de administración, ni de dirección.

La vigilancia no comprende el control, aunque el control sí podría abarcar funciones de vigilancia. Más adelante se explican las relaciones entre estos dos conceptos. 
La señora Procuradora General, no obstante haber hecho la acertada afirmación que se mencionó al inicio de este epígrafe, también incurrió en mezcla y confusión de normas constitucionales con normas legales, al afirmar lo siguiente:

[...] debe hablarse primero de la función fiscalizadora de la Contraloría respecto de la Hacienda Pública y en tal tema la sentencia 2011-4835 así como las normas legales incluidas en la Ley Orgánica de la Contraloría y la Ley de Control Interno. Por su parte la autonomía universitaria también está recogida en la Constitución y en la jurisprudencia constitucional y es con esos dos marcos de referencia que debe resolverse la acción $[\ldots]^{53}$

La autonomía universitaria tiene rango constitucional. Las normas contenidas en la Ley Orgánica de la Contraloría y en la Ley General de Control Interno tienen un rango jurídico puramente legal. La primera, la autonomía — de rango constitucional — prevalece sobre las segundas — de rango legal-. Estas últimas no pueden modificar el alcance de la primera, ni reducirlo, ni condicionarlo. 
No existe incompatibilidad ni contraposición de funciones entre las actividades desarrolladas por la Universidad estatal, en ejercicio de su amplia autonomía, y la labor de vigilancia que corresponde a la Contraloría General. Tal vigilancia no ha sido estorbada por el Instituto Tecnológico, que tampoco ha alegado inmunidades legislativas, soberanías, o extraterritorialidades (ante la función de vigilancia). Sin embargo, esta compatibilidad no se refiere a la autonomía universitaria en relación con el control, que es una función muy diferente de la vigilancia.

La señora Subcontralora, por su parte, manifestó lo siguiente:

[...] La autonomía [universitaria] se refiere a los fines que se persiguen y en este caso la normativa y la materia están relacionados con un fin como es el control de la Hacienda Pública, tema que sí es de competencia de la Contraloría General [...] 
La autonomía no puede quedar reducida a los "fines" de la Universidad sino que es muchísimo más amplia, como lo establece la Constitución Política. Abarca, desde luego, también todos los "medios" para lograr esos fines. El control de la hacienda pública es una función atribuida por ley común u ordinaria a la Contraloría General y jamás puede cercenar ni disminuir la plena capacidad jurídica que tienen las Universidades estatales para auto organizarse y autogobernarse y para ejercitar sus funciones de modo independiente.

El control pretendido por la Contraloría General sí implica interferencia y lesión al ámbito legítimo de la autonomía universitaria. El Instituto Tecnológico de Costa Rica interpuso la acción de inconstitucionalidad como reacción contra la indebida e injustificada intervención de la Contraloría General de la República en las funciones universitarias, en la organización universitaria y en el gobierno universitario.

La Constitución Política no otorga potestades de control a la Contraloría General de la República, como sí lo hace — en forma expresa - respecto a las funciones de vigilancia de la hacienda pública.

\section{El control de la Contraloría General}


En la Ley Orgánica de la Contraloría General de la República, desde su primera disposición, se mezcla y confunde la fiscalización (o vigilancia ${ }^{54}$ ) con el control de la hacienda pública:

Artículo 1.- Naturaleza jurídica y atribución general. La Contraloría General de la República es un órgano constitucional fundamental del Estado, auxiliar de la Asamblea Legislativa en el control superior de la Hacienda Pública y rector del sistema de fiscalización que contempla esta Ley. ${ }^{55}$

La Constitución Política, como ya se ha expresado, no confiere a la Contraloría General atribuciones de control, ni de control superior, de la hacienda pública, ni tampoco le otorga carácter de rector del sistema de fiscalización. Tales atribuciones y tal carácter le son otorgados por esta Ley Orgánica, que es una ley común y corriente. No son otorgados, se insiste nuevamente, por la Constitución Política.

La señora Subcontralora General, al referirse a la acción de inconstitucionalidad, afirmó algo que no es cierto. Expresó lo siguiente:

[...] En el caso de las Universidades, se tiene que manejan fondos públicos de modo que es pacíficamente aceptado que pueden ser sujetos [de] control y fiscalización, todo en relación con el manejo de los fondos públicos [... $]^{56}$ 
Debido a la peculiar naturaleza jurídica de la Universidad estatal costarricense, las funciones - constitucionales- de fiscalización (o de vigilancia) de la Contraloría General no pueden entremezclarse ni, mucho menos, confundirse con las atribuciones - legales - de control. El Instituto Tecnológico y también la Universidad de Costa Rica no han aceptado, ni mucho menos han aceptado pacíficamente, que puedan ser objeto de control por parte de la Contraloría General.

Es posible que la Contraloría General, de conformidad con las facultades que la ley le ha atribuido - la ley común u ordinaria- pueda interferir en la organización y en el gobierno de otras instituciones públicas que sí puedan ser objeto de control, distintas de las Universidades estatales.

Como esas otras instituciones públicas carecen de la autonomía — con todos sus distintos aspectos o facetas indisolublemente unidos-que sí poseen las Universidades estatales en una forma muy amplia, sí resulta posible que se les puedan aplicar (a esas otras instituciones) las disposiciones de control, con todas sus graves implicaciones, por haber sido así establecido por las leyes, que sí pueden regular la organización, el gobierno, la administración, las funciones y el patrimonio de esas otras instituciones (que no son Universidades estatales). 
¿Qué es control?, ¿Qué actividades se encuentran incorporadas en la noción de control?, ¿Por qué las Universidades estatales no están sujetas, ni aceptan el control de la Contraloría General?

Una valiosa aproximación para dar respuesta a estas preguntas puede obtenerse del siguiente autorizado texto:

La palabra control tiene dos sentidos registrados por la Academia: 'inspección, fiscalización, intervención' y 'dominio, mando': El portero lleva el control de las personas que llegan y salen. El ejército tiene el control de la situación. Como hay contextos en los que el sentido de control resulta ambiguo, es aconsejable sustituir este término, en su segundo sentido, por dominio o mando, pues en esta acepción no es tan necesario como en la primera el uso de control: El ejército tiene el dominio de la situación. La misma observación vale para el verbo controlar: El ejército domina (mejor que controla) la situación. ${ }^{57}$ 
Según esto, la palabra control tiene dos significados principales: 1) inspección, fiscalización, intervención, y 2) dominio, mando ${ }^{58}$ Como se expresó con anterioridad, el control implica la fiscalización, pero ésta no comprende el control. La fiscalización (o vigilancia) es una acción analítica y de estudio que no interfiere en las actividades del ente fiscalizado, ni en su estructura, ni en su administración, ni en su gobierno.

El control implica la posibilidad de intervención en el ente controlado y también presupone un estado de subordinación del ente controlado, que se encuentra bajo el dominio o mando del órgano controlador. El control, por tanto, presupone la existencia de una supremacía del órgano controlador sobre la institución controlada. Implica una subordinación del ente controlado con respecto al controlador.

La Constitución Política no ha ubicado a la Contraloría General de la República en un nivel superior, del cual dependan jerárquicamente las Universidades estatales. Estas instituciones de cultura superior se encuentran ubicadas al más alto nivel de la organización política del Estado costarricense y por ello poseen plena capacidad jurídica para autogobernarse y para auto organizarse. Las Universidades estatales no se encuentran sometidas a obediencia, ni a dominio, ni a mando respecto de la Contraloría General de la República. 
Para establecer cuál es el ordenamiento jurídico aplicable a las Universidades estatales es preciso situarse en el más alto nivel de las fuentes del Derecho y evitar esa mezcla confusa e impropia de normas constitucionales y legales como si tuvieran el mismo rango jurídico- en que han incurrido la Contraloría General, la Sala Constitucional y la Procuraduría General.

La Constitución Política establece la autonomía universitaria con los alcances expuestos en líneas anteriores y también establece las funciones constitucionales (valga la insistencia) de la Contraloría General de la República.

Las atribuciones que le confiere la Constitución Política a la Contraloría General, en lo que aquí interesa, versan únicamente sobre la vigilancia de la hacienda pública ${ }^{59}$ y, a lo sumo, sobre la evaluación de resultados y rendición de cuentas. ${ }^{60}$ Como estas atribuciones se encuentran establecidas directamente en la Carta Magna, tienen naturaleza jurídica de funciones constitucionales. 
La señora Procuradora General al referirse a la acción de inconstitucionalidad también había expresado que

[...] en cuanto a las disposiciones de control interno y las normas técnicas, puede ser que parezca que interfieren en la organización de las Universidades y por tanto en el ámbito reservado a ellas, pero no es así pues, entiende la Procuraduría que las disposiciones sobre control interno que se emiten en el ámbito de la fiscalización constituyen un límite a la capacidad de darse su propia organización que tienen las Universidades estatales [...]

¿En qué se fundamenta la señora Procuradora para entender que existe un límite a la plena capacidad jurídica para auto organizarse y gobernarse que otorga la Constitución Política a las Universidades estatales?

Tal consideración suya cae por su propio peso. La plena capacidad jurídica que tienen las Universidades estatales para darse su propia organización — cuyo origen es la Constitución Política- jamás puede quedar limitada o restringida por disposiciones sobre control interno — cuya fuente es la ley común u ordinaria, subordinada a la Constitución Política—. Una norma inferior jamás puede reducir los alcances de una norma superior. ${ }^{61}$ 
No se trata tan solo de una apariencia, como indica la señora Procuradora, sino de que realmente las disposiciones de control y las normas técnicas (también de control) sí interfieren en el ámbito de organización y gobierno de las Universidades estatales y, por tanto, su aplicación a las instituciones universitarias es contraria a la Constitución Política.

La Constitución Política no confiere a la Contraloría General atribuciones de control superior de la hacienda pública, ni de rector del sistema de fiscalización, lo que sí se establece por una ley ordinaria, la Ley Orgánica de la Contraloría General de la República (artículo 1º, antes transcrito). Estas otras atribuciones poseen naturaleza jurídica inferior a la Constitución. Estas otras funciones de la Contraloría, establecidas mediante leyes ordinarias, se encuentran subordinadas a las normas constitucionales. Se encuentran subordinadas a la disposición constitucional que consagra la autonomía universitaria. Las normas inferiores no prevalecen sobre las superiores. Las normas inferiores no pueden igualarse a las normas superiores. Las disposiciones de carácter puramente legal no pueden dejar sin efecto los alcances de una autonomía universitaria consagrada en la Constitución Política. 
Una cosa es la vigilancia o fiscalización de la hacienda pública universitaria y otra, muy diferente, es el control que pueda ejercer la Contraloría General sobre otras instituciones públicas o privadas que administren y dispongan de fondos públicos.

La Contraloría General de la República — sin tener carácter de superior jerárquico suyo - giró un conjunto de órdenes específicas al Instituto Tecnológico: ordenó al Presidente de la Asamblea Institucional

Las órdenes de la Contraloría General

Representativa convocar a sesión extraordinaria de este órgano colegiado;

ordenó a la Asamblea Institucional Representativa prohibir el desempeño simultáneo de funciones de Coordinador General y Coordinador de Proyecto; ordenó a la Asamblea Institucional Representativa modificar un Reglamento para definir las funciones del Coordinador General y del Coordinador de Proyecto y prohibir su desempeño simultáneo; para cada una de estas órdenes fijó plazos y la obligación de comunicar su cumplimiento a la Contraloría General.

La Contraloría General emitió un conjunto de órdenes al Instituto Tecnológico que constituyen materia propia de las funciones, del gobierno y de la organización de esta Universidad estatal. Estas órdenes exceden en mucho la 
labor de vigilancia de la hacienda pública universitaria, que compete a ese órgano auxiliar de la Asamblea Legislativa. Se podría pensar que se enmarcan dentro del control. Pero la Contraloría General no ejerce control alguno sobre las Universidades estatales, en ninguna función, en ninguna materia, en ningún aspecto o faceta de su autonomía.

El Instituto Tecnológico accionante había expresado que, con respecto a los puntos objetados por la Contraloría General,

[...] el Reglamento actual contempla una fórmula que en su criterio [del Instituto] satisface las exigencias de la normativa sobre control interno pero que el informe final de la Contraloría hizo caso omiso de ello y dispone una estructura particular [...]

Ni la Contraloría General, ni la Sala Constitucional, analizaron esta cuestión. Cualquier modificación en la organización de la institución corresponde — no en primer lugar, sino exclusivamente - al Instituto Tecnológico. Si por aspectos de conveniencia o de disminución racional de riesgos resultara recomendable hacer tal modificación y la consecuente reforma reglamentaria, 
tales decisiones solo compete tomarlas al propio Instituto Tecnológico. Nunca, a la Contraloría General de la República. Este órgano auxiliar de la Asamblea Legislativa puede emitir recomendaciones técnicas o, incluso, jurídicas. Pero su aplicación únicamente corresponde a la Universidad estatal, luego de haberlas analizado y valorado y, sobre todo, después de haberlas adoptado, después de haberlas hecho propias.

Con la omisión de la Contraloría en constatar la solución aportada por el Instituto Tecnológico, la violación a la autonomía universitaria adquiere mayor gravedad. El Instituto Tecnológico ya había solucionado el problema y la Contraloría lo ignoró y le impuso — arbitrariamente - la obligación de adoptar una estructura particular.

La señora Procuradora General advirtió la existencia de esta violación a la autonomía universitaria. En la acción de inconstitucionalidad se estaba cuestionando

[...] la obligación de acatar las normas técnicas que emita la Contraloría y en particular las disposiciones concretas que en uso de esa facultad se emitieron $[\ldots]$ 
La Procuraduría General de la República afirmó, al respecto que

[...] sí se encuentra una infracción a la Constitución Política en lo dispuesto por ente contralor, en cuanto a las órdenes emitidas respecto a cuáles órganos deben convocarse, cuándo deben convocarse y en cuáles sesiones se deben adoptar los acuerdos destinados cumplir con lo dispuesto por la Contraloría [...]

Sin embargo, la Sala Constitucional en la resolución que aquí se comenta consideró que

[...] mientras el contenido de las actuaciones de la Contraloría en este caso se ubique dentro de esa labor de control de la actividad administrativa, sus acciones son constitucionales y no existe posibilidad jurídica de que se vean limitadas por el régimen de autonomía del que goza el Instituto Tecnológico de Costa Rica.- La razón para lo anterior es que tales regímenes de autonomía apuntan al reconocimiento de grados mayores o menores de discreción para ciertos entes, pero no respecto del conjunto de las actividades administrativas en el que opera la Contraloría, sino más bien -frente al Ejecutivo y en ocasiones al Legislativo, pues lo que buscan es una mayor flexibilidad para la programación de metas hacia el logro de sus fines y la asignación de medios y recursos que estimen apropiados para lograrlos. 
Como puede notarse, la Sala Constitucional abandona el texto de la Constitución Política respecto a la actividad de vigilancia de la hacienda pública, que compete a la Contraloría General, y se circunscribe a aplicar la noción de control de la actividad administrativa que se encuentra establecida como función de la Contraloría General, a lo sumo, en una ley común u ordinaria y no en la Constitución Política.

Los distintos regímenes de autonomía existentes en el ordenamiento jurídico costarricense implican, es cierto, mayores o menores grados de discrecionalidad. Discrecional significa: 1. adj. Que se hace libre y prudencialmente. 2. adj. Se dice de la potestad gubernativa en las funciones de su competencia que no están regladas. 3. [... ${ }^{62}$.

La autonomía universitaria no es una simple discrecionalidad. La autonomía universitaria es mucho más que discrecionalidad. Es independencia en todas las funciones propias. Es plena capacidad jurídica para organizarse, para gobernarse, para contratar. La independencia universitaria y la inexistencia de normas que rijan sus funciones constituyen parte de la dimensión externa de la autonomía. La autonomía comprende, también, una dimensión interna: la amplísima libertad en todas sus funciones (incluyendo la libertad de cátedra) y, en forma positiva, la plena capacidad jurídica que le corresponde por disposición de la Constitución Política. 
Mal se entiende la autonomía universitaria si se le conceptúa, como la ha hecho erróneamente la Sala Constitucional en el párrafo antes citado, como una mayor flexibilidad para la programación de metas y como la asignación de medios y recursos apropiados para lograrlas. No. La autonomía universitaria no es una flexibilidad para programar fines y asignar medios. Basta traer a colación nuevamente el contenido del artículo 84 de la Constitución Política para constatar, sin gran esfuerzo mental, que la amplia autonomía universitaria jamás puede quedar reducida a una simple flexibilidad. Tal afirmación, aunque provenga de la Sala Constitucional, es gravemente irrespetuosa para las Universidades estatales.

En las instituciones públicas en las que la Contraloría General puede ejercer el control (no en las Universidades estatales) no debe restringirse la discrecionalidad que les corresponde. La Contraloría no puede tomar decisiones que competen a las instituciones, no puede administrarlas, no puede gobernarlas, no puede estructurarlas. La Contraloría no debería ser administración activa. No debería serlo, pero de hecho lo es. Lo es cuando, so pretexto de ejercitar el control, interviene, interfiere, sustituye o suplanta a las instituciones controladas. Girar órdenes de supuesto cumplimiento obligatorio, como si se fuera superior jerárquico, ¿no es ejercer, con toda claridad, una administración activa? ${ }^{63}$ 
¿Cuál es el "conjunto de las actividades administrativas en el que opera la Contraloría”, al que se refirió la Sala Constitucional en el párrafo recién transcrito? Para dar respuesta correcta a esta pregunta es necesario distinguir cuáles de esas actividades provienen de la Constitución Política y cuáles otras provienen de la ley común u ordinaria.

A las Universidades públicas solamente se les puede aplicar las funciones de vigilancia de la hacienda pública atribuidas en la Constitución Política a la Contraloría General.

A los demás órganos y entidades de derecho público, y a algunos de derecho privado que manejan fondos públicos, se les aplican todas las atribuciones de la Contraloría General, originadas tanto en la Constitución Política, como en las leyes comunes u ordinarias. 
En el considerando V, la Sala Constitucional, a propósito de la actuación de la Contraloría General en este asunto, expresó:

[...] está plenamente enmarcado dentro de las actividades administrativas de control a su cargo, pues en primer lugar, lejos de influir o disponer sobre los fines del Instituto o bien sobre los medios para lograrlos, las medidas discutidas tienen un claro fin de control, pues solamente buscan evitar que se produzca el desempeño en forma simultánea, por parte de una sola persona, de las funciones de Coordinador General y Coordinador específico [...]

Las distintas órdenes giradas por la Contraloría General al Instituto Tecnológico no son consecuencia de su función de vigilancia de la hacienda pública, sino — como lo expresa la Sala Constitucional— se trata de actividades administrativas de control. Las Universidades estatales no están supeditadas al control de la Contraloría General.

El tribunal constitucional se circunscribió tan solo a examinar si esas actividades administrativas de control (que no se aplican a las Universidades estatales) incidían o no sobre los fines del Instituto Tecnológico, o sobre los 
medios requeridos para lograrlos. La autonomía universitaria no está restringida a los fines o a los medios para lograr esos fines. La autonomía universitaria abarca, inescindiblemente, al menos los seis aspectos o facetas establecidos por la Constitución Política, descritos y comentados con anterioridad. Las órdenes de la Contraloría General interfieren la autonomía del Instituto Tecnológico porque violan su capacidad jurídica plena de organización y de gobierno y su independencia de funciones.

El razonamiento de la Sala Constitucional no quedó allí. En el considerando VI insistió de la siguiente manera:

[...] el régimen de autonomía del Instituto Tecnológico no le es oponible a la actividad administrativa de control atribuida constitucionalmente a la Contraloría, entonces, no existe razón jurídica alguna para sostener que ese mismo régimen de autonomía obligue al ente $[\mathrm{sic}]^{64}$ contralor a señalar lo que debe hacerse para corregir la situación pero sin poder instruir actos específicos necesarios que considere oportuno tomar para el logro del fin de control buscado.- [...] nada impide a la Contraloría imponerle al instituto accionante obligaciones concretas de hacer [...] si bien existen grados de autonomía, ello se repite, no operan a nivel de la actividad de control, respecto de la cual, constitucionalmente, todos los entes y órganos controlados soportan esencialmente el mismo régimen jurídico de sometimiento $[\ldots]$ 
Es necesario repetir hasta la saciedad que la Constitución Política no otorga facultades de control a la Contraloría General de la República, sino solo de vigilancia. Es necesario repetir que la autonomía universitaria está consagrada en el texto constitucional. Es necesario repetir que las atribuciones de control que posee la Contraloría provienen de leyes simples, comunes u ordinarias y que estas leyes poseen un rango inferior al de las normas constitucionales.

La autonomía universitaria prevalece sobre las funciones legales de control de la Contraloría. El control — de origen legal— de la Contraloría no puede cercenar, condicionar, ni desconocer el rango constitucional superior de la autonomía universitaria. A las Universidades estatales no se les aplica el control de la Contraloría General. Las Universidades estatales no están subordinadas ni están sometidas a régimen jurídico alguno de control de la Contraloría General. En sus funciones de vigilancia, la Contraloría General no puede imponerle a las Universidades estatales obligación alguna de hacer algo concreto, como tampoco algo genérico. ${ }^{65}$ 
Otros argumentos esbozados por la señora Subcontralora General fueron los siguientes:

[...] Correctamente entendido las Universidades no podrían estar ajenas al ordenamiento jurídico relacionado con la Hacienda Pública y, en particular, no podría[n] estar ajena[s] [a] la normativa, órdenes y disposiciones que le dirija la Contraloría $[\ldots]^{66}$

Y, más adelante, insiste en lo mismo:

[...] el control interno es un componente de la Hacienda Pública [...] y [...] al ser la Contraloría el órgano superior en materia de control interno, no cabe duda de la posibilidad de que ella emita disposiciones de acatamiento obligatorio, lo cual de por sí está expresamente expresado en el artículo 12 de la Ley número 7428, con las cuales se busca garantizar el buen uso de fondos públicos [... ${ }^{67}$ 
Debe resaltarse que no compete al legislador definir conceptos ni términos. La asignación de significado a las palabras no le corresponde a la Asamblea Legislativa. A propósito de la hacienda pública, el artículo 8 de la Ley Orgánica de la Contraloría General de la República intenta establecer qué debe entenderse como hacienda pública. Al hacerlo, junto a los fondos públicos, incorpora la potestades para percibir, administrar, custodiar... tales fondos, lo mismo que las normas jurídicas relativas al proceso presupuestario, la contratación administrativa, el control interno y externo y la responsabilidad de los funcionarios públicos. También incluye, como sujetos componentes de la hacienda pública, al Estado y a los demás entes u órganos públicos, estatales o no... 68

El Título XIII de la Constitución Política se denomina "La hacienda pública" y contiene tres capítulos referidos al presupuesto de la República, a la Contraloría General de la República y a la Tesorería Nacional, ninguno de los cuales se refiere a potestades, ni a normas jurídicas, ni a sujetos componentes, relacionados con la hacienda pública.

Hacienda pública es sinónimo de erario, de fisco, de tesoro público. Es un concepto patrimonial, es decir, un conjunto de activos y de pasivos. Las potestades, las normas jurídicas y los órganos o entes no pueden enmarcarse como activos o como pasivos en un universo patrimonial. 
Independientemente de la discusión acerca del abuso legislativo en la definición de conceptos o palabras, la noción amplia de hacienda pública — que incluye los bienes, los restantes activos y los pasivos, de las Universidades públicas - no permite entender jamás que la Constitución Política hubiera atribuido función alguna de control de la hacienda pública a la Contraloría General.

Respecto de la hacienda pública, las únicas funciones que atribuye la Constitución Política a la Contraloría General son las de vigilancia. No las de control, a pesar de lo que haya expuesto o considerado - con lamentable y evidente error- la Sala Constitucional.

La Contraloría General de la República carece de cualquier atribución de control sobre las Universidades estatales. No posee potestad alguna de control sobre la hacienda universitaria.

¿Por qué existe un régimen jurídico especial de las Universidades estatales, diferente del régimen jurídico aplicable al resto de las instituciones públicas? Este régimen jurídico especial - autonomía universitaria - corresponde a la autónoma y las universidades peculiar naturaleza de las Universidades. 
La Administración pública, en sentido amplio, está constituida por el Estadopersona y por los demás entes públicos. ${ }^{69}$ Abarca tanto la Administración centralizada como la descentralizada. Incluye también a las Universidades estatales. ${ }^{70}$ Sin embargo, las Universidades no pueden ser consideradas como un componente más en ese conjunto. La autonomía — con todos sus alcancesde que están dotadas por disposición de la Constitución Política impide un tratamiento igualitario. Como se ha expuesto, no se trata del sometimiento a un régimen jurídico excepcional, sino de constatar y utilizar las disposiciones jurídicas aplicables, conforme a la naturaleza propia de las Universidades y a su rango constitucionalmente establecido.

El régimen jurídico especial propio de las Universidades se corresponde con su naturaleza. Esta concordancia del régimen jurídico y la naturaleza no ha sido ocurrencia espontánea del constituyente costarricense. Para entender su naturaleza propia y su particular régimen jurídico es indispensable entender qué es, qué ha sido y qué debe ser la Universidad. La cuestión no es ociosa. La Universidad se ha visto afectada por un considerable aumento demográfico. Por otra parte, las ramas de la Ciencia han proliferado. De alguna forma todo esto ha provocado cambios en la Universidad y ha dado origen al surgimiento de numerosos centros de formación superior que también - y erróneamentese han venido denominando universidades. 
Muchos de estos centros de educación superior han sido orientados hacia la preparación de profesionales o de técnicos, cuya formación dista mucho de la verdadera formación universitaria. Las Universidades estatales no han sido totalmente inmunes a esta orientación. La indebida mezcla de lo universitario con lo que no lo es, ha provocado la disminución de las características propias de la Universidad. Una universidad así diluida no necesitaría de la autonomía. La autonomía universitaria, vista desde esta degradada noción de universidad, resultaría algo superfluo e injustificado. Constituiría —en este deformado concepto de universidad - una excepción a las normas generales, sería un conjunto de prerrogativas ilegítimas. Una universidad pública cuyo propósito único fuera la formación de profesionales o de técnicos se distinguiría en muy poco de una fábrica o de una industria pertenecientes al Estado.

Una universidad tal se encontraría al servicio del Estado o del Gobierno y a tal universidad estatal se le aplicarían, sin excepción alguna, todas las disposiciones - constitucionales y legales - de la Contraloría General de la República en lo que se refiere a fiscalización y a un amplio concepto de control. 
Pero la Universidad — la verdadera Universidad - no es eso. La Universidad es el lugar de la búsqueda de la verdad, de la investigación y de elaboración de la ciencia, de la transmisión de los saberes con sentido de totalidad; es el lugar específico de la posesión refleja de la cultura y de la emergencia de la persona humana. ${ }^{71}$ La Universidad no es una simple fábrica de profesionales. Además de formar profesionales preparados y de formar ciudadanos que puedan ejercitar responsablemente su libertad, la Universidad debe velar para que el verdadero universitario adquiera una capacidad crítica, ${ }^{72}$ una madurez, una auténtica formación cultural, un enriquecimiento en su ser personal.

El espíritu crítico se apoya en una preocupación intelectual, que lleva a una dedicación esforzada al estudio, premisa de cualquier juicio valorativo. El estudio, entendido universitariamente, es afán por conocer — cada uno desde el campo propio de las distintas Escuelas o Facultades, pero con una aspiración cultivada al saber de totalidad - la situación en la sociedad y por obtener la base cultural que permita a cada uno proyectarse sobre los demás, sobre su país y, en definitiva, sobre la humanidad. ${ }^{73}$

Si la capacidad de crítica se apoya en el estudio, tiene a la vez como presupuesto el ejercicio de la humildad intelectual, que se manifiesta en la alegría de aprender de lo que saben otros, en el respeto a las convicciones de 
los demás, y en la experiencia de que la búsqueda de la verdad, siendo responsabilidad personal, es sin embargo tarea social, la más noble tarea social y comunitaria. La humildad intelectual implica, por otra parte, la conciencia clara de las propias limitaciones y estar atentos a detectar en la propia vida intelectual todas las formas de autoafirmación y de envidia. Muchas de las formas de criticismo — de falta de verdadera capacidad crítica — tal vez tengan aquí su raíz. ${ }^{74}$

Una persona que viva la verdadera vida universitaria, tiene que ser humilde porque se ve eslabón de una cadena, y experimenta la limitación de sus propios conocimientos y la necesidad de contar con el trabajo de otros. Eso facilita escuchar a los demás: otros saben cosas que yo no sé, debo fiarme del trabajo de otros. Sin humildad intelectual no hay auténtica colaboración universitaria ni trabajo en equipo. ${ }^{75}$

El hábito de la convivencia social, de participar en un equipo de trabajo universitario; de encontrarse después con los mismos compañeros y con otras personas, en otro tipo de actividades en las que uno conoce y aprecia el modo de ser y de opinar de las otras personas y aprende a querer y respetar, a escuchar, a dialogar, en definitiva, a convivir. Y no por razones tácticas, con finalidad utilitaria, algo que podría llamarse coexistencia de egoístas. No: al 
universitario que piensa le interesan realmente los otros, sus ideas, sus particulares enfoques de los problemas, sus aportaciones. ${ }^{76}$

$\mathrm{Si}$, pensando en los años del porvenir más próximo, la Universidad no consigue entregar promociones de universitarios a la sociedad - para la vida profesional, para la gestión social y política en las estructuras sociales - con esta capacidad de discernimiento, de análisis, de decir la verdad, aunque duela; con esta especie de sobriedad en el modo de adherirse a las cosas y este hábito de respeto y de convivencia, podría dar origen a una sociedad desde cuya estructura se podría manipular y oprimir masivamente a la persona humana. ${ }^{77}$

La Universidad no puede ser reflejo de la realidad social. No puede ser una consecuencia del estado actual de una sociedad, ni de un Gobierno. La Universidad, aunque inmersa en la sociedad, debe estar sobre ella y sobre el Gobierno, como conciencia lúcida, como conciencia moral de una nación. Debe estar en plena capacidad de poder ejercitar con absoluta libertad la crítica positiva, respetuosa, constructiva de toda la realidad, inclusive de las actuaciones de las autoridades gubernamentales. La Universidad debe ser un lugar de encuentro de ideas, de formación de opiniones, de búsqueda incansable de la Verdad, del Bien, de la Belleza, de la Justicia. Su actividad es 
esencialmente libre. No admite coacciones, limitaciones, condicionamientos ni, mucho menos, órdenes, directrices o lineamientos de nadie. La Universidad estatal costarricense carece de superior jerárquico. La Contraloría General de la República no puede arrogarse o auto atribuirse carácter de superior de las Universidades.

A propósito de qué es o qué debe ser la Universidad, en los Principios fundamentales de la "Carta Magna de las Universidades de Europa”, suscrita el 18 de setiembre de 1988 con ocasión del IX Centenario de la fundación de la Universidad de Bolonia, en una forma muy elocuente, se expresó lo siguiente:

1. La Universidad [...] es una institución autónoma que, de manera crítica, produce y transmite la cultura por medio de la investigación y la enseñanza. Para abrirse a las necesidades del mundo contemporáneo, debe lograr, en su esfuerzo de investigación y enseñanza, una independencia moral y científica de todo poder político y económico. 2. En las Universidades, la actividad docente es indisociable de la actividad investigadora, a fin de que la enseñanza siga tanto la evolución de las necesidades como las exigencias de la sociedad y de los conocimientos científicos. 3. La libertad de investigación, de enseñanza y 
de formación son el principio fundamental de la vida de las Universidades; los poderes públicos y las Universidades, cada uno en su esfera de competencias, deben garantizar y promover el respeto a esta exigencia fundamental. El rechazo de la intolerancia y el diálogo permanente hacen de la Universidad un lugar de encuentro privilegiado entre profesores, que tienen la capacidad de transmitir el saber y los medios de desarrollarlo mediante la investigación y la innovación, y estudiantes que tienen el derecho, la voluntad y la capacidad de enriquecerse con ello. 4. Depositaria de la tradición del humanismo europeo, pero con la constante preocupación de atender al saber universal, la Universidad, para asumir su misión, ignora toda frontera geográfica o política y afirma la necesidad imperiosa del conocimiento recíproco y de la interacción de las culturas. ${ }^{78}$

Uno de esos rasgos, que interesa subrayar en el presente análisis, es la necesidad de un amplio espacio de libertad para el desarrollo de las actividades universitarias. La Universidad requiere de una independencia moral y científica de todo poder político y económico. La libertad de investigación, de enseñanza y de formación son principio fundamental de la vida de las Universidades; los poderes públicos y las Universidades, cada uno en su esfera de competencias, deben garantizar y promover el respeto a esta exigencia fundamental. ${ }^{79}$ 
Mal se puede entender que a una Institución tal, de tan alta autoridad, de tan alta dignidad — lo mismo que a sus representantes - la Contraloría General de la República le gire órdenes específicas, le señale plazos para su cumplimiento y le exija dar cuenta de la obediente sumisión a las instrucciones emitidas. Peor se puede entender esto cuando tales órdenes provienen de funcionarios inferiores, subordinados en tercer o cuarto grado, de ese órgano auxiliar de la Asamblea Legislativa, que no ostentan las funciones ni las responsabilidades del Contralor General.

Las erradas interpretaciones de la Contraloría General, de la Sala Constitucional y de la Procuraduría General lamentablemente lesionan no solo la autonomía universitaria, sino también la institucionalidad del Estado costarricense $^{80}$, ya que pretenden en forma ilegítima justificar una arbitraria injerencia en aspectos básicos del gobierno, organización y funciones de las Universidades estatales, como ha sucedido en este caso en perjuicio del Instituto Tecnológico de Costa Rica. 
Cuando se discutía el sistema de financiamiento de la Universidad de Costa Rica en la Asamblea Nacional Constituyente, don Rodrigo Facio hizo una brillante exposición y manifestó algo que se aplica no solo al aspecto o faceta

\section{Una} consideración final de la financiación estatal, sino a cualquiera de los otros que, como ha quedado expuesto antes, se encuentran todos interrelacionados e indivisible y armónicamente unidos. Expresó lo siguiente:

[...] Llegamos a la conclusión de que sólo un abogado puede haber para la Universidad: el propio texto de la Constitución [.... $]^{81}$

El mejor defensor de la Universidad es el propio texto de la Constitución. No las interpretaciones antojadizas de la Contraloría General. No las consideraciones erróneas de la Sala Constitucional. No los conceptos equivocados de la Procuraduría General.

Luego de haberse examinado con detenimiento la resolución número 9215 dictada por la Sala Constitucional a las 14:30 horas del 17 de julio de 2012, se llega a la conclusión de que hubiera sido preferible que el Instituto Tecnológico de Costa Rica no hubiera interpuesto la acción de inconstitucionalidad que presentó. Los pésimos resultados obtenidos eran, francamente, previsibles. 
Ante una acción arbitraria y prepotente de la Contraloría General de la República, lo que corresponde es simplemente hacer caso omiso de ella. Deber de obediencia existe respecto del funcionario, órgano o ente que tenga legítimo carácter de superior jerárquico.

La Constitución Política consagra, como se ha expuesto tantas veces, una amplísima autonomía para las Universidades estatales, con aspectos o facetas claramente identificados, que se encuentran inescindiblemente unidos. La misma Constitución Política no establece que la Contraloría General ostente condición de superior jerárquico de las Universidades.

Ni la ley, ni la caprichosa interpretación que haga la Contraloría General, autorizan desconocimiento alguno de la autonomía universitaria consagrada por la Constitución Política, norma jurídica suprema que debe ser respetada por todos, incluyendo a la Contraloría General, a la Sala Constitucional, a la Procuraduría General.

La defensa de la autonomía universitaria se encuentra en el propio texto constitucional. Para defender su autonomía, basta con que las Universidades estatales invoquen la existencia de la Constitución Política y ejerciten — directa e inmediatamente - las facultades y atribuciones conferidas en el texto 
constitucional. Ejercicio en forma directa, es decir, sin necesidad de la intermediación de nadie (ni siquiera de la Sala Constitucional). Ejercicio inmediato de los derechos constitucionales, es decir, sin necesidad de esperar la aceptación o el convencimiento de la Contraloría General. Las actuaciones de quien carece de facultades jurídicas para ejecutarlas son absolutamente nulas. ${ }^{82}$ Como la Contraloría General no posee legítimas facultades jurídicas de control sobre las Universidades estatales, ni ostenta carácter de superior jerárquico propio ni impropio de ellas, sus órdenes resultan absolutamente nulas, son jurídicamente inexistentes. Por tanto, pueden $-\mathrm{y}$ deben - ser ignoradas.

Todo esto vale ante el caso concreto de las órdenes giradas al Instituto Tecnológico de Costa Rica. Pero vale también frente a las frecuentes pretensiones de la Contraloría General, entre otras, relacionadas con el sistema y las condiciones de nombramiento del auditor interno, con la intervención decisoria de la Contraloría General ${ }^{83}$, el carácter obligatorio de las recomendaciones contenidas en los informes de auditoría interna ${ }^{84}$, la subordinación del jerarca del ente público a la decisión de la Contraloría General $^{85}$, el carácter obligatorio de las disposiciones, normas, políticas y directrices emitidas por la Contraloría General ${ }^{86}$. 
1. Ver artículo 84 de la Constitución Política.

2. Las instituciones autónomas tienen independencia administrativa pero están sujetas a la ley en materia de gobierno (artículo 188 de la Constitución Política).

3. Ver artículo 73 de la Constitución Política.

4. Ver artículos 169 y 170 de la Constitución Política. Las Municipalidades están sujetas a la organización establecida por la ley (Código Municipal).

5. Cfr. http://www.vinv.ucr.ac.cr/blog/?p=58 Consultado el 26 de marzo de 2014. Con referencia a ese acontecimiento, el Consejo Nacional de Rectores acordó lo siguiente: "A.- Censurar enérgicamente la actuación de los funcionarios del Organismo de Investigación Judicial (OIJ), que ingresaron abruptamente el pasado 12 de abril al campus de la Universidad de Costa Rica, sin la debida coordinación con las autoridades universitarias competentes, hechos que sin duda, violentan la autonomía universitaria. Nunca una Universidad ha defendido hechos delictivos, ni ha protegido delincuentes, ni permitiremos nunca que en nuestras instituciones se den actuaciones al margen de la Ley y del orden público. B.- Manifestar nuestra solidaridad 
incondicional con la defensa de la autonomía y el respeto por la Universidad de Costa Rica. C.- Hacer un fuerte llamado a las y los estudiantes y al cuerpo institucional, para que, con la serenidad y el respeto que nos caracteriza y que nos otorga la academia y nuestro buen juicio, no se permitan nuevos disturbios que afecten la buena marcha institucional."

6. Cfr. http://ministeriopublico.poderjudicial.go.cr/noticias/2010/Mayo/Unidad\%20Fraudes\%20allano\% 20oficinas \%20administrativas\%20del\%20TEC-\%2020-05.html Consultado el 26 marzo de 2014.

7. La nota se identifica con el protocolo DFOE-SOC-1196 del 29 de octubre de 2010 y el informe con el DFOE-SOC-IF-75-2010 del 19 de octubre de 2010. Ambos pueden ser consultados en la página electrónica de la Contraloría General de la República.

8. Mediante nota DFOE-SOC-1195, al Departamento Financiero Contable le fue ordenado lo siguiente: “4.4. (...) Diseñar $e$ implementar controles que garanticen el correcto y oportuno traslado de los recursos por parte de FUNDATEC, correspondientes al FDI y FDU, en los que participen las unidades operativas que ejecutan programas y proyectos en el marco del vínculo remunerado, como contraparte institucional y 
responsables de su adecuado manejo. Los controles que se diseñen en cumplimiento de esta disposición, deberán ser informados a esta Contraloría General a más tardar el 28 de febrero de 2011 ...”

9. En el citado informe DFOE-SOC-IF-75-2010 fueron indicadas como órdenes de acatamiento obligatorio, además de otras, las siguientes:

"4.1. Al Presidente de la Asamblea Institucional Representativa: Convocar a la Asamblea Institucional Representativa, dentro de los 3 días hábiles posteriores al recibo de este informe a una sesión extraordinaria a realizarse a más tardar el 16 de diciembre de 2010, a efectos de que ese órgano conozca las disposiciones emitidas a esa Asamblea y tome el acuerdo correspondiente, según lo solicitado en la disposición 4.2 a). Deberá remitirse a esta Contraloría copia de la convocatoria realizada antes del 30 de noviembre de 2010. b) Incluir dentro de la convocatoria y en el orden del día para las sesiones ordinarias de marzo y setiembre de 2011, el asunto relativo a las modificaciones al Reglamento para la Vinculación Remunerada Externa, solicitadas a la Asamblea institucional Representativa en la disposición 4.2 b) de este informe. Deberán remitirse a esta Contraloría General, las respectivas convocatorias y orden del día, el 15 de febrero de 2011 para la primera y el 16 de agosto de 2011 para la segunda. 
4.2. A la Asamblea Institucional Representativa:

a) Dictar acuerdo para que en forma inmediata se prohíba el desempeño simultáneo de las funciones de Coordinador General y Coordinador de Proyecto (específico) por parte de una sola persona, con el propósito de fortalecer el control de los programas y proyectos y dar cumplimiento a lo que establece la norma No. 2.5.3 del Manual de normas generales de control interno para la Contraloría General de la República y las entidades y órganos sujetos a su fiscalización, mientras se realizan las modificaciones al Reglamento para la Vinculación Remunerada Externa. El acuerdo que se dicte en cumplimiento de esta disposición, deberá tomarse en la próxima sesión extraordinaria a realizar por ese órgano, y ser comunicado a esta Contraloría General a más tardar el 17 de diciembre de 2010.

b) Dictar acuerdo mediante el cual se ordene la modificación del Reglamento para la Vinculación Remunerada Externa de forma tal que se definan claramente las funciones del Coordinador General y del Coordinador de Proyecto (Específico) y se prohíba en forma terminante el desempeño simultáneo de esos puestos por parte de una sola persona, con el propósito de fortalecer el control de los programas y proyectos, dar cumplimiento a lo que establece la norma No. 2.5.3 del Manual de normas generales de control 
interno para la Contraloría General de la República y las entidades y órganos sujetos a su fiscalización y prevenir situaciones que podrían ir en detrimento del vínculo remunerado del ITCR. El acuerdo que se dicte en cumplimiento de esta disposición, deberá tomarse en la sesión ordinaria a realizar en marzo de 2011 y ser comunicado a esta Contraloría General a más tardar el 15 de abril de 2011. Asimismo, la modificación que se realice al Reglamento deberá aprobarse en la sesión ordinaria a realizar en setiembre de 2011 y comunicarse a esta Contraloría General a más tardar el 15 de octubre de 2011. Al respecto, obsérvese el comentario 2.1.2 a) de este informe."

También fueron giradas otras órdenes al Departamento Financiero Contable y a la Directora Ejecutiva de FUNDATEC.

10. El delito de desobediencia se encuentra tipificado por el artículo 314 del Código Penal: "Se impondrá prisión de seis meses a tres años, a quien no cumpla o no haga cumplir, en todos sus extremos, la orden impartida por un órgano jurisdiccional o por un funcionario público en el ejercicio de sus funciones, siempre que se haya comunicado personalmente, salvo si se trata de la propia detención." A este delito hace referencia el artículo 68 de la Ley Orgánica de la Contraloría General de la República. Sin embargo, en la nota en cuestión no se alude en modo alguno a esta figura penal, sino únicamente a las sanciones previstas por el artículo 69 
de dicha Ley Orgánica. El delito de desobediencia presupone la existencia de un legítimo deber de obediencia que, en este asunto, no se da. La funcionaria del Área de Servicios Sociales de la Contraloría carece de facultades para girar órdenes a funcionarios u órganos del Instituto Tecnológico.

11. Así lo establece el mencionado artículo 69. Antes de "imponer" la sanción al infractor, la Contraloría dará audiencia para que justifique el incumplimiento y vencido el plazo, resolverá.

12. Artículo 70 de la Ley Orgánica de la Contraloría General de la República.

13. Así se dispone en el último párrafo del este artículo 70. Estas atribuciones a la Presidencia de la República se corresponden con las facultades que le otorga la Ley General de la Administración Pública: "Dirigir y coordinar las tareas de Gobierno y de la Administración Pública central en su total conjunto, y hacer lo propio con la Administración Pública descentralizada" (artículo 26, inciso b). También compete a la Presidencia de la República resolver los motivos de abstención de un órgano administrativo que carezca de superior jerárquico (artículos 232 y 234). 
14. La Asamblea Institucional Representativa es la máxima autoridad de esta institución. Artículo 5 del Estatuto Orgánico. Cfr http://www.itcr.ac.cr/reglamentos/Consultas/consultarR1.asp?n=41 9 Consultado el 26 de marzo de 2014.

15. Cfr. Artículo 11 del Estatuto Orgánico.

16. Cfr. Artículo 18, inciso f), del Estatuto Orgánico. No compete al Consejo Institucional la materia referente a reglamentos sobre “... funcionamiento de la Asamblea Institucional Representativa y del Congreso Institucional".

17. Cfr. Considerando I de la resolución número 9215 dictada por la Sala Constitucional a las 14:30 horas del 17 de julio de 2012, expediente número 11-007916-0007-CO.

18. Resolución dictada a las 14:30 horas del 17 de julio de 2012.

19. La Ley de la Jurisdicción Constitucional, en su artículo 73, inciso b), también permite la interposición de la acción de inconstitucionalidad contra los actos subjetivos de las autoridades públicas, que infrinjan alguna norma o principio constitucional, siempre que no fueren susceptibles de los recursos de hábeas corpus o de amparo. La acción de inconstitucionalidad se dirige, principalmente, contra las leyes y otras disposiciones generales contrarias a la Constitución Política. 
20. Las Universidades estatales costarricenses son cinco: la Universidad de Costa Rica, la Universidad Nacional Autónoma, el Instituto Tecnológico de Costa Rica, la Universidad Estatal a Distancia y la Universidad Técnica Nacional. Esta última no participa aún del financiamiento proveniente del Fondo especial para el financiamiento de la Educación Superior Estatal (FEES). Ver artículo 85 de la Constitución Política.

21. De modo deliberado escribo la expresión "hacienda pública" sin mayúsculas. No se trata de un nombre propio, ni de una entidad, ni de un órgano, sino de un simple conjunto o universalidad patrimonial. La misma razón vale para las palabras erario, tesoro o fisco.

22. Muchas disposiciones de la Constitución Política hacen remisión a la ley. Ver artículos 14, 17, 19, 23, 24, 26, 29, 31, 41, 45, 46, 47, 49, 50, 53, 58, 59, 73, 74, 78, 80, 82, 92, 95, 96, 102 (inciso 10), 105, 147, 152, 154, 159, 162, 168, 170, 171, 172, 173, 174, 186 у 188.

23. Cfr. Diccionario de la Real Academia Española, versión digital, 22a ed. (2011) consultado el 28 de febrero de 2014 en http://buscon.rae.es/drae/?type=3\&val=graf\%EDa\&val_aux=\&orige n=REDRAE En la 21ª edición, impresa, (Madrid, 1992), la voz contraloría significa "en algunos países de América, servicio encargado de examinar la legalidad y corrección de los gastos públicos". 
24. Cfr. Diccionario de la Real Academia Española, versión digital, 22a ed. (2011) consultado el 28 de febrero de 2014 en http://buscon.rae.es/drae/?type=3\&val=graf\%EDa\&val_aux=\&orig en=REDRAE La palabra contralor deriva del francés contrôleur. En la 21ª edición, impresa, (Madrid, 1992), el término contralor significa "en algunos países de América, funcionario encargado de examinar la legalidad y corrección de los gastos oficiales”. Además, el verbo contralorear significa "poner el contralor su aprobación, o refrendar los despachos de su oficio”.

25. Cfr. Diccionario de la Real Academia Española, versión digital, 22a ed. (2011) consultado el 28 de febrero de 2014 en http://buscon.rae.es/drae/?type=3\&val=graf\%EDa\&val_aux=\&orig en=REDRAE Según la 21ª edición, impresa, (Madrid, 1992), la palabra controlar (del francés contrôler) significa "ejercer el control".

26. Ver artículos 183 y 184 de la Constitución Política.

27. Así lo dispone el inciso $5^{\circ}$ del artículo 184. La Constitución establece algunas pocas funciones más: ver artículos 179, 180 y 181. En el párrafo segundo del inciso $1^{\circ}$ del artículo 184 se estipula que "no se emitirá ninguna orden de pago contra los fondos del Estado sino cuando el gasto respectivo haya sido visado por la Contraloría; ni constituirá obligación para el Estado la que no 
haya sido refrendada por ella." Es muy importante distinguir las funciones que la Constitución Política otorga a la Contraloría General de otras funciones, adicionales, que la ley común u ordinaria le atribuya. No debe confundirse el rango constitucional con el nivel puramente legal. Lo establecido por el inciso $5^{\circ} \mathrm{del}$ artículo 184 no otorga carácter constitucional a las competencias o funciones dispuestas por una ley común (subordinada a la Constitución).

28. Ver Ley Orgánica de la Contraloría General de la República, N ${ }^{\circ}$ 7428 del 7 de setiembre de 1994 y Ley General de Control Interno No 8292 del 31 de julio de 2002.

29. Artículo 129 de la Constitución Política.

30. Artículo 33, ibíd.

31. Voz "privilegio" en Diccionario de la Real Academia Española, (21ª edición, Madrid, 1992).

32. El artículo 84 de la Constitución Política otorga a la Universidad estatal, entre otros extremos, "[...] independencia para el desempeño de sus funciones [...] ". Se trata de funciones relacionadas con la cultura superior y con la educación superior universitaria. Corresponde a la propia Universidad definir cuáles son todas esas funciones y qué extensión y profundidad deben tener 
las actividades propias de docencia, investigación y acción social. Esas funciones comprenden, asimismo, el gobierno, la organización y la contratación.

33. Al afirmarse que la Universidad pública ejerce de algún modo una porción importante de la soberanía no se está incurriendo en el delito de traición a la Patria (artículos 2 y 3 de la Constitución Política), sino que se está significando el carácter soberano que corresponde a la institución universitaria. La Real Academia Española de la Lengua otorga a la voz "soberano, na" las siguientes acepciones: “1. adj. Que ejerce o posee la autoridad suprema e independiente. Apl. a pers., u. t. c. s. // 2. adj. Elevado, excelente y no superado.// 3. adj. ant. Altivo, soberbio o presumido." Cfr. http://buscon.rae.es/drae/?type=3\&val=soberano\&val_aux=\&orige n=REDRAE Consultado el 26 marzo de 2014. (Diccionario de la Real Academia Española, 23 ${ }^{\mathrm{a}}$ edición). Esta antigua tercera acepción no es aplicable, pero sí las dos primeras. En consecuencia, puede hablarse con propiedad del ejercicio directo de la soberanía por parte de la Universidad estatal.

34. Sala Constitucional, resolución número 1313 de 1993, considerando VI.- SIGNIFICACIÓN DEL CONCEPTO DE AUTONOMÍA. 
35. Sala Constitucional, resolución número 1313 de 1993, considerando VII.LOS LÍMITES DE LA POTESTAD LEGISLATIVA EN RELACIÓN CON LA AUTONOMÍA UNIVERSITARIA. Ver también resolución de la Sala Constitucional número 6256 de 1994, de 9:oo horas del 25 de octubre de 1994. Las leyes a las que se refiere el artículo 88 de la Constitución, relacionadas con las materias puestas bajo la competencia de la Universidades estatales, aunque resulte evidente manifestarlo, son leyes ordinarias o comunes y no pueden derogar, ni modificar el régimen constitucional propio de dichas instituciones de cultura superior.

36. La señora Subcontralora, hoy Contralora General, al referirse a la acción de inconstitucionalidad, expresó que el Instituto Tecnológico accionante planteaba una visión distorsionada de la autonomía, incompatible con la fiscalización de fondos públicos de las Universidades y que tal labor no puede ser estorbada por autonomías o ámbitos funcionales. También expresó que no existen inmunidades legislativas, ni soberanías, ni extraterritorialidades a favor de las Universidades. El Instituto accionante no argumentó la extraterritorialidad en momento alguno, lo que convierte en superfluo este punto del argumento de la señora Subcontralora. Para refutar todas sus afirmaciones, basta leer bien y con atención el texto de la Constitución Política. El Instituto Tecnológico no ha obstaculizado las tareas de vigilancia o de fiscalización - de rango constitucional- que corresponden a la Contraloría General. 
37. Las Universidades estatales, no obstante poseer una amplia autonomía, no quedan comprendidas dentro de la instituciones autónomas a las que se refieren los artículos 188 y 189 de la Constitución Política, que están dotadas, únicamente de independencia administrativa y que se encuentran sujetas a la ley en materia de gobierno.

38. Ver al respecto resolución, citada anteriormente, número 6256 de 1994 de la Sala Constitucional: “... Existen en nuestro ordenamiento jurídico tres formas de autonomía: a) administrativa, que es la posibilidad jurídica de que un ente realice su cometido legal por sí mismo sin sujeción a otro ente, conocida en doctrina como la capacidad de autoadministración; b) política, que es la capacidad de autodirigirse políticamente, de autogobernarse, de dictarse el ente a sí mismo sus propios objetivos; y c) organizativa, que es la capacidad de auto organizarse, con exclusión de toda potestad legislativa. En los dos primeros casos, la autonomía es frente al Poder Ejecutivo y en el tercero, también frente al Poder Legislativo. La autonomía organizativa es propia de las universidades según se desprende del artículo 84 de la Constitución Política..." 
39. En el considerando IV de la resolución 11473 de 2012, la Sala Constitucional, sin ninguna fundamentación restringe la capacidad jurídica plena de las Universidades estatales para reglamentarse indicando que "El artículo 84 de la Constitución Política establece una reserva normativa en favor de las universidades, en el sentido de que su poder reglamentario es el único competente para normar la organización del servicio universitario..." La reserva normativa universitaria no se refiere únicamente a la organización, sino que comprende también el gobierno, la plena capacidad jurídica para adquirir derechos y contraer obligaciones y, en general, todas sus funciones, que ejerce en forma independiente.

40. Ver supra, resolución de la Sala Constitucional número 6256 de 1994.

41. El artículo 154 de la Constitución Política dispone que el Poder Judicial sólo está sometido a la Constitución y a la ley. El Juez, por tanto, no es un funcionario subordinado. Al juzgar, está juzgando como Poder Judicial, como Estado costarricense, sin depender en sus funciones de superior jerárquico (ni de Jueces superiores, ni de Magistrados, ni de órgano judicial alguno). En cierta forma, al juzgar, está ejerciendo in actu la soberanía, el gobierno o la potestad pública; es un órgano estatal, es el Estado personificado, actuante. 
42. El Diccionario de la Real Academia Española define la voz "dotar" así: (...) 2. tr. Señalar bienes para una fundación o instituto benéfico. (...) 4. tr. Asignar a una oficina, a un buque, a un establecimiento público, etc., el número de empleados y los enseres que le son necesarios. 5. tr. Asignar sueldo o haber a un empleo o cargo cualquiera. 6 . http://buscon.rae.es/drae/?type $=3 \& v a l=d o t a r \& v a l \_a u x=\& o r i g e n=R$ EDRAE Es conveniente hacer notar que el Estado, al cumplir con la obligación constitucional de dotar de patrimonio a las Universidades estatales les transmite bienes y recursos suficientes a título gratuito, no a título oneroso.

43. Don Fernando Baudrit Solera ocupaba el cargo de Rector de la Universidad de Costa Rica. Participó en la Comisión Redactora del Proyecto de Constitución Política de la Segunda República. En el artículo 91 de este Proyecto se propuso que el Estado dotaría de patrimonio, crearía las rentas necesarias a la Universidad de Costa Rica y contribuiría a su mantenimiento con una suma no menor del diez por ciento del presupuesto anual de gastos del Ministerio de Educación (ver Actas, Imp. Nacional, San José, 1957, tomo I, p. 36). El impulso y defensa a la autonomía universitaria por parte del Rector, en funciones de Diputado constituyente, puede constatarse especialmente en el Acta número 160, 4 de octubre de 1949), Actas (Imp. Nacional, San José, 1957), tomo III, pp. 394-396. 
44. Exposición del Diputado Gonzalo Ortiz Martín (Acta número 160, 4 de octubre de 1949), Actas (Imp. Nacional, San José, 1957), tomo III, pp. 387-388 y 402-403.

45. Exposición del Representante Fernando Fournier Acuña. Ibid., p. 396.

46. Galdames, Luis, La Universidad autónoma (Ed. Borrasé, San José, 1935) p. 84.

47. Cfr. los estudios Repensar la autonomía de la Universidad de Costa Rica (Oficina Jurídica UCR, Ciudad Universitaria Rodrigo Facio, Siedin, 2005) y Autonomía universitaria y control de la hacienda pública, (Oficina Jurídica UCR, Ciudad Universitaria Rodrigo Facio, Siedin, 2009).

48. El artículo 183 de la Constitución establece que la Contraloría General es una institución auxiliar de la Asamblea Legislativa en la vigilancia de la hacienda pública. El artículo 11, reformado en junio de 2000, establece el sometimiento de la Administración Pública, en sentido amplio, a un procedimiento de evaluación de resultados y rendición de cuentas y que la ley señalará los medios para que este control de resultados y rendición de cuentas opere como un sistema que cubra todas las instituciones públicas. La Ley Orgánica de la Contraloría General No 7428 del 7 de setiembre de 
1994 es anterior a esa reforma constitucional y no regula los medios para un control de resultados y de rendición de cuentas. Este control de resultados y rendición de cuentas, en cualquier caso, constituye una actividad de fiscalización o de vigilancia $a$ posteriori y en ningún caso puede autorizar la intervención de la Contraloría General en la gestión ni en las decisiones propias del órgano o ente obligado a ese procedimiento. Desde que en el año 2000se reformó el artículo 11 de la Constitución Política y se estableció la necesidad de un control de resultados y rendición de cuentas no ha sido aprobada ley alguna que lo disponga (ver artículo del profesor Miguel Sobrado, "La Sala IV y el artículo 11 de la Constitución”, publicado en el diario La Nación el 3 de abril de 2014.

49. Ver

http://buscon.rae.es/drae/?type=3\&val=vigilar\&val_aux=\&origen= REDRAE (Diccionario de la Real Academia Española, $23^{\text {a }}$ edición).

50. Ver http://buscon.rae.es/drae/?type=3\&val=velar\&val_aux=\&origen=R EDRAE (Diccionario de la Real Academia Española, 23 a edición).

51. Cfr. oficio OJ-149-2011 de la Oficina Jurídica. 
52. Cfr. art. 196 del Código de Comercio. En las asociaciones, el órgano fiscalía es diferente del órgano director, ver art. 10 de la Ley de Asociaciones.

53. La citada resolución 2011-4835 de la Sala Constitucional se refiere a un recurso de amparo en el que se impugnó el procedimiento médico utilizado para tratar una fractura, que fue rechazado de plano. No tiene relación alguna con los argumentos expuestos por la señora Procuradora General. La referencia a esa resolución se encuentra equivocada.

54. Resulta curioso hacer notar que en la Ley Orgánica de la Contraloría General de la República No 7428 de 7 de setiembre de 1994 no aparece, ni una sola vez, la palabra vigilancia, ni el verbo vigilar. La palabra fiscalización sí aparece en más de cuarenta oportunidades.

55. Al control también se refiere de la Ley Orgánica de la Contraloría General de la República, en múltiples ocasiones, entre otras, en sus artículos 4, 5, 6, 10, 11, 12, 13, 17, 24, 25, 31, 36, 37.

56. En apoyo a su aseveración, la señora Subcontralora mencionó la resolución de la Sala Constitucional número 16 del año 1995, relacionada con la Caja Costarricense de Seguro Social, institución autónoma que carece de aspectos o facetas de la autonomía propia 
de la Universidad. También citó la resolución — pendiente aún de redacción— - de ese mismo tribunal número 123 del año 1991 en la que se ordena acumulación en un recurso de amparo, cuyo ponente fue el Magistrado Rodolfo Piza Escalante, según se lee en la página web de esa Sala. ¿Qué apoyo puede brindar una resolución sin redactar? Nuevamente, se constata otra referencia equivocada en los argumentos de la Contraloría.

57. Manuel Seco, Diccionario de dudas y dificultades de la lengua española (10ª ed., Espasa-Calpe, Madrid, 2004) p. 132. En sentido similar, un reconocido filólogo costarricense escribió: "La palabra 'control', de origen francés (controle), pasó a nuestro idioma con el sentido de inspección, fiscalización, intervención, lo mismo que de mando, preponderancia, etc. En su odisea semántica por el inglés adquirió nuevos sentidos que, naturalmente, no pasaron al español, como el de 'combatir', 'exterminar', 'acabar con', etc." Cristián Rodríguez Estrada, Filólogo y Periodista, recopilación de Aura Rosa Vargas Araya (UNED, San José, 1988) p. 167.

58. El Diccionario de la Real Academia Española (23 a edición) define "control" de esta manera: "(Del fr. contrôle) 1. m. Comprobación, inspección, fiscalización, intervención. 2. m. Dominio, mando, preponderancia. (...)" Cfr.

http://buscon.rae.es/drae/?type=3\&val=control\&val_aux=\&origen= REDRAE 
59. Artículo 183.

60. Artículo 184 inciso $4^{\circ}$, y artículo 11. El artículo 11 establece, al final, que "La ley señalará los medios para que este control de resultados y rendición de cuentas opere como un sistema que cubra todas las instituciones públicas". Es necesario insistir en que este control no se refiere al manejo de fondos públicos, como con error lo indica la señora Subcontralora, sino únicamente a los resultados y a la rendición de cuentas.

61. En materia de interpretación y aplicación de las normas jurídicas se aplica la regla lex superior derogat inferior, la norma jurídica superior prevalece sobre la inferior. La norma constitucional se impone sobre la norma legal.

62. Cfr.

http://buscon.rae.es/drae/?type=3\&val=discrecional\&val_aux=\&ori gen $=$ REDRAE

63. El artículo 65 (hoy derogado) de la Ley Orgánica de la Contraloría General de la República establecía para este órgano auxiliar de la Asamblea Legislativa la prohibición de realizar funciones de administración activa. Este artículo fue derogado por la Ley General de Control Interno. Curiosamente, en las normas vigentes 
de la Ley Orgánica de la Contraloría, como en las de la Ley General de Control interno, se omite toda referencia a que la Contraloría General tenga prohibición de realizar funciones de administración activa. La única prohibición para ser administración activa se establece en la Ley General de Control Interno con respecto al auditor interno (artículo 34, a).

64. La Contraloría General de la República no es un ente. Carece de personería jurídica. Es una institución auxiliar de la Asamblea Legislativa, es decir, un simple órgano administrativo que posee independencia funcional y administrativa en el desempeño de sus funciones (artículo 183 de la Constitución Política).

65. Un guardia o un centinela cuidan desde fuera: no se entrometen en las funciones. Vigilar es velar o atender cuidadosamente algo. No es "regular", ni reglamentar. No es interferir en la gestión. No es ordenar que se ejecute determinado acto. No es asumir la posición de superior jerárquico. No es ejercer potestad disciplinaria alguna. Tampoco es obsérvese con detenimiento- ejercer acciones de control, de mando, de intervención. Desde luego, la vigilancia no permite tampoco al vigilante que sustituya o suplante al titular del patrimonio universitario. La Contraloría General no es administradora de la hacienda universitaria, ni tiene facultad alguna para disponer de ella, ni para inmiscuirse en el gobierno, en la organización, ni en la administración, ni en las funciones universitarias. 
66. En apoyo a sus afirmaciones, la señora Subcontralora citas dos sentencias de la Sala Constitucional que no vienen al caso. Cfr. supra notas 53 y 56 .

67. En contraste radical con este celo de la Contraloría General para garantizar el buen uso de los fondos públicos, la señora Contralora General (anterior Subcontralora) escribió y publicó lo siguiente: “...El refrendo, como control previo externo a ese proceso, está absolutamente delimitado a efecto de no invadir o coadministrar en competencias exclusivas de la Administración. Por esa razón, el actual Reglamento de Refrendo se ocupa de clarificar que se trata de un acto aprobatorio y no de un medio para auditar el proceso realizado por la Administración o anular lo adjudicado. (...) la decisión del mecanismo para desarrollar la infraestructura pública es de resorte exclusivo de la Administración, sin espacio alguno para que un órgano de control externo se refiera a criterios de oportunidad y conveniencia en la escogencia de ese mecanismo de contratación... ” Acosta Zúñiga, Marta, Refrendo y control de legalidad, diario La Nación, 28 de abril de 2013, p. 30-A. En asuntos tan importantes y tan cuantiosos (para la hacienda pública), como es el desarrollo de la infraestructura vial en el país, la Contraloría General pareciera renunciar a sus funciones 
constitucionales de vigilancia y a sus funciones legales de control de la hacienda pública, mientras que - aunque no se tratara de un refrendo- para ordenarle al Instituto Tecnológico que no puede permitir que un Coordinador general de proyectos sea también Coordinador específico de uno de ellos — sin tener atribuciones de control para ello-, dice poseer amplias facultades para organizar, para gobernar, para asumir determinadas funciones propias de esa Universidad estatal y, como si fuera su superior jerárquico, para ordenarle que cumpla con mandamientos específicos dentro de plazos determinados, con obligación de informar del obediente cumplimiento. Para negar que la Contraloría General haya asumido atribuciones y potestades de organización, de gobierno y de funciones del Instituto Tecnológico de Costa Rica, para negar que haya asumido funciones de administración activa de esa Universidad estatal, es necesario tergiversar los conceptos y el significado de las palabras.

68. Al conjunto de estos sujetos componentes se le denomina Administración pública (Artículo $1^{\circ}$ de la Ley General de la Administración Pública). No por ello se encuentran sometidos a idéntico régimen jurídico. La Administración universitaria no puede quedar subsumida en la Administración pública ni confundida con ella. 
69. Cfr. Artículo $1^{\circ}$ de la Ley General de la Administración Pública.

70. Las Universidades estatales no se encuentran dentro de la esfera de poder del Gobierno, pero tampoco pueden ser enmarcadas dentro de las instituciones autónomas, ni dentro de las instituciones descentralizadas, tal como las regulan —a estas dos últimas— la Constitución Política y las leyes. Las Universidades estatales, conforme a su autonomía de rango constitucional, poseen una naturaleza jurídica peculiar: independencia de funciones y plena capacidad jurídica para gobernarse, para organizarse, para contratar. Cfr. Repensar la autonomía de la Universidad de Costa Rica, supra nota 46.

71. Estas ideas, y las que siguen, han sido tomadas y adaptadas de Rodríguez, P., Naturaleza, cultura, universidad, HUMANITAS (número 35) http://www.humanitas.cl/html/biblioteca/articulos/528.html

72. Diferente a la capacidad crítica es el criticismo, fruto de una generalizada cultura de la sospecha. La crítica es método, camino para avanzar desde la verdad conocida hacia la verdad que se busca descubrir y conocer. La capacidad de crítica es un "estilo", algo que no se improvisa, sino que es fruto laborioso de una formación 
seria y del ejercicio cotidiano de los actos propios del quehacer universitario, de los hábitos que surgen de la auténtica convivencia universitaria. Ibíd.

73. Ibíd.

74. Ibíd.

75. Ibíd.

76. Ibíd.

77. Ibíd.

78. Cfr. http://www.uspceu.es/CNTRGF/RGF_europa_1445.html

79. Cfr. J.M. Mora Universidades de inspiración cristiana: identidad, cultura, comunicación ROMANA (N 54, 2012) p. 197.

80. La lesión a la institucionalidad del Estado costarricenses no es una afirmación baladí. Es muy grave y muy serio que, por exceso y abuso en sus funciones, la Contraloría General y la Sala Constitucional hayan ido perdiendo autoridad, es decir, hayan ido perdiendo peso y calidad en sus resoluciones y dictámenes. De la justificada desobediencia a órdenes ilegítimas, muy fácilmente se puede pasar a la desobediencia a disposiciones legítimas. Esto cabe aplicarlo también a las leyes ilegítimas. 
81. Asamblea Nacional Constituyente de 1949, Actas (Imp. Nacional, San José, 1957) Acta No 160, tomo III, p. 398.

82. La Ley Orgánica del Poder Judicial establece en su artículo 168:

"Salvo disposición legal en contrario, todos los actos y procedimientos judiciales de quien no tiene facultad legal para ejecutarlos, serán absolutamente nulos." Aunque esta disposición legal se refiere a los tribunales y funcionarios judiciales, resulta perfectamente aplicable también a los otros funcionarios públicos.

83. Artículo 31 de la Ley General de Control Interno.

84. Artículo 36 de la Ley General de Control Interno.

85. Artículo 38 de la Ley General de Control Interno.

86. Artículo 12 de la Ley Orgánica de la Contraloría General. 